\title{
Human migration into Europe during the late Early Pleistocene climate transition
}

\author{
Giovanni Muttoni ${ }^{\mathrm{a}, *}$, Giancarlo Scardia ${ }^{\mathrm{b}}$, Dennis V. Kent ${ }^{\mathrm{c}}$ \\ a Department of Earth Sciences, University of Milan, via Mangiagalli 34, I-20133 Milan, Italy, E ALP-Alpine Laboratory of Paleomagnetism, via Madonna dei Boschi 76, \\ I-12016 Peveragno (CN), Italy \\ ${ }^{\mathrm{b}}$ Istituto Nazionale di Geofisica e Vulcanologia, Sezione di Milano-Pavia, via Bassini 15, I-20133 Milano, Italy \\ ' Department of Earth and Planetary Sciences, Rutgers University, Piscataway, NJ 08854, USA, E Lamont-Doherty Earth Observatory, Palisades, NY 10964, USA
}

\section{A R T I C L E I N F O}

\section{Article history:}

Received 1 February 2010

Received in revised form 23 June 2010

Accepted 27 June 2010

Available online 23 July 2010

\section{Keywords:}

Pleistocene

Magnetostratigraphy

Hominins

Migration

Europe

Galerian

Jaramillo

Brunhes-Matuyama

Climate transition

\begin{abstract}
A B S T R A C T
A critical assesment of the available magnetostratigraphic and/or radiometric age constraints on key sites bearing hominin remains and/or lithic industries from southern Europe (Italy, France, Spain) leads us to propose that the main window of early hominin presence in southern Europe is broadly comprised between the Jaramillo subchron and the Brunhes-Matuyama boundary (i.e., subchron C1r.1r, 0.99-0.78 Ma). Within the dating uncertainties, this $\sim 200$ ky time window broadly coincides with the late Early Pleistocene global climate transition that contains marine isotope stage (MIS) $22(\sim 0.87 \mathrm{Ma})$, the first prominent cold stage of the Pleistocene. We suggest that aridification in North Africa and Eastern Europe, particularly harsh during MIS 22 times, triggered migration pulses of large herbivores, particularly elephants, from these regions into southern European refugia, and that hominins migrated with them. Finally, we speculate on common pathways of late Early Pleistocene dispersal of elephants and hominins from their home in savannah Africa to southern Europe, elephant and hominin buen retiro. In particular, we stress the importance of the Po Valley of northern Italy that became largely and permanently exposed only since MIS 22, thus allowing possibly for the first time in the Pleistocene viable new migration routes for large mammals and hominins across northern Italy to southern France and Spain in the west.
\end{abstract}

(c) 2010 Elsevier B.V. All rights reserved.

\section{Introduction}

The pioneering magnetostratigraphic study of Parés and PérezGonzalez (1995) provided the first robust evidence for the presence of hominins in northern Spain at Gran Dolina (Carbonell et al., 1995) (Fig. 1) as early as the Early Pleistocene, specifically, sometime in the late Matuyama reverse polarity chron between the BrunhesMatuyama boundary $(0.78 \mathrm{Ma})$ and probably after the Jaramillo normal subchron (0.99 Ma). A very similar magnetostratigraphic profile placing evidence of hominins in reverse polarity sediments just below a transition correlated to the Brunhes-Matuyama boundary was reported at the nearby site of Sima del Elefante by Parés et al. (2006). However, more recently reported cosmogenic burial dates from Sima del Elefante seem to indicate that hominin occupation was earlier at around 1.1-1.2 Ma (Carbonell et al., 2008), which would be in the Matuyama prior to the Jaramillo. In the Guadix-Baza Basin of southern Spain, hominin sites first dated to a generic pre-BrunhesMatuyama boundary interval (Oms et al., 2000) have been recently reassigned to a pre-Jaramillo age interval of $1.2-1.25 \mathrm{Ma}$ using magnetostratigraphic data from a composite profile (Scott et al., 2007). In this regard, a candidate for the oldest site in Europe may as

\footnotetext{
* Corresponding author.

E-mail address: giovanni.muttoni1@unimi.it (G. Muttoni).
}

well be represented by the apparently even older site of Pirro Nord in southern Italy (Fig. 1), where biostratigraphic-based arguments were used to indicate hominin occupation sometime in the 1.3-1.7 Ma time range (Arzarello et al., 2007).

Although the evidence that Spain was occupied sometime before the Brunhes-Matuyama boundary is well documented, the precise timing of first colonization of southern Europe remains a complicated issue because age estimates of key sites, including those in Spain mentioned above, are controversial (e.g., Dennell and Roebroeks, 1996; Villa, 2001; Roebroeks, 2001; Antón and Swisher, 2004). This is also well exemplified by the case of the Ceprano man, thought to have lived in central Italy around the Brunhes-Matuyama boundary (Manzi, 2004) until a recent study showed that rather than being a candidate for one of the oldest occupation sites in southern Europe, the homininbearing level was in fact only 0.45 Myr-old (Muttoni et al., 2009).

Accordingly, we attempt in this paper a critical assessment of the age data of key sites from southern Europe (Italy, France, Spain) bearing early hominin remains (bones, teeth) and/or Mode I or Mode II lithic tools. Mode I tools, also known as Oldowan, were produced in Africa as early as 2.6-2.5 Ma (Semaw et al., 1997; Quade et al., 2004) by simple lithic reduction strategies involving the use of hammerstones to detach flakes from pebble cores. Mode II tools, also known as Acheulian, were produced in Africa as early as $\sim 1.6-1.5 \mathrm{Ma}$ (Asfaw et al., 1992; Quade et al., 2004) by more elaborate technologies involving shaping and retouching of stones to produce biface tools, and are therefore much less 


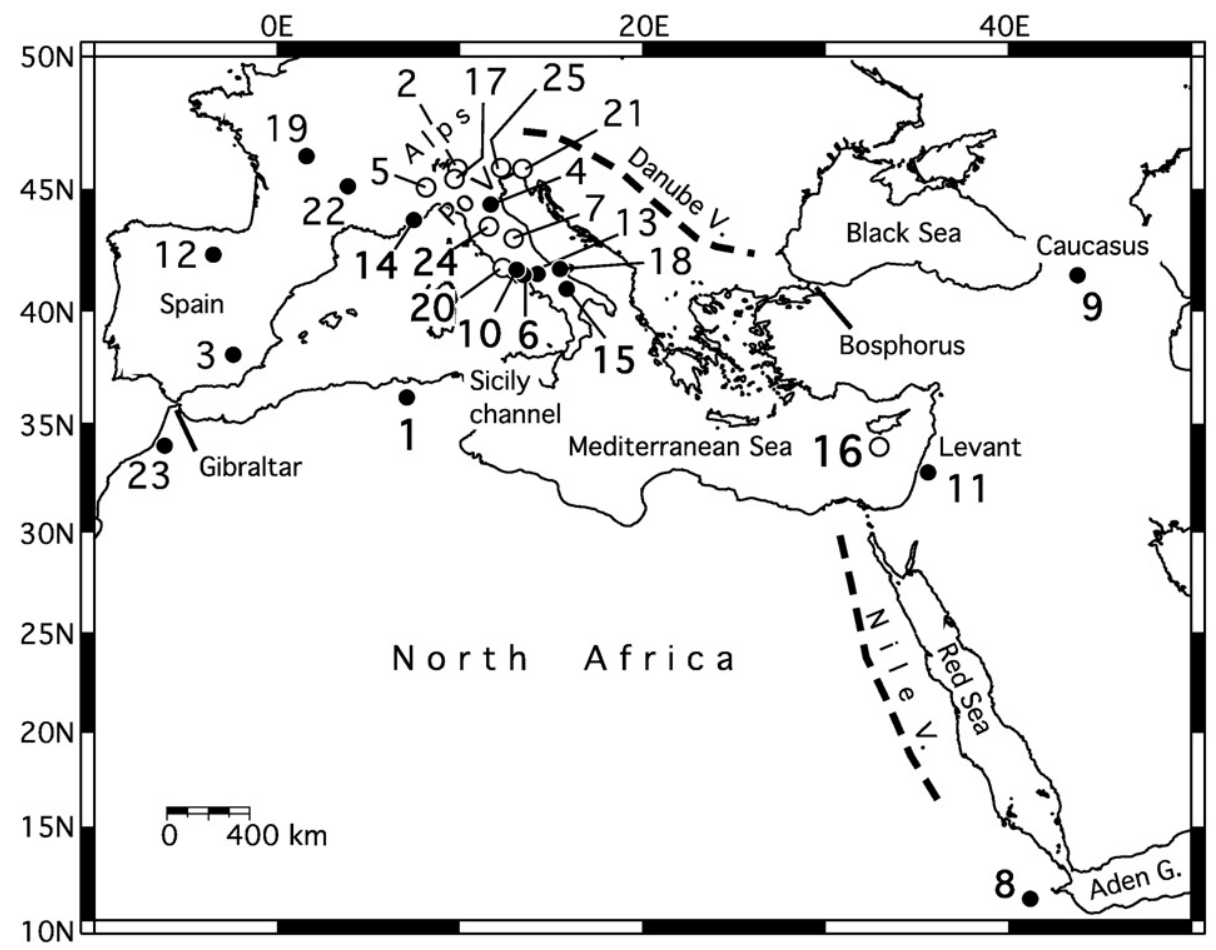

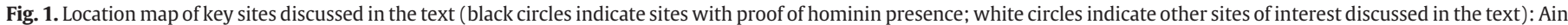

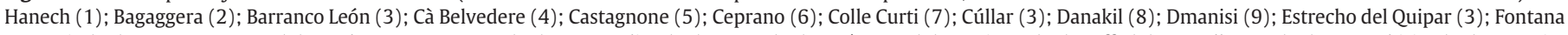

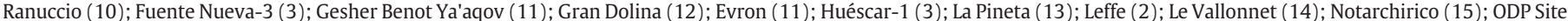

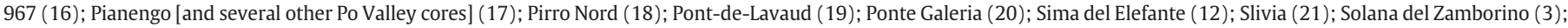
Soleilhac (22); Thomas Quarry (23); 'Ubeidiya (11); Upper Valdarno (24); Venice (25).

likely to be confused with artifact-like phenomena of geological origin (geofacts; Haynes, 1973). For our analysis, the distinction between Mode I and Mode II technologies has virtually no chronologic significance insofar as Mode II artifacts were well known by Africans when Mode I tools were still being used by the earliest Europeans (e.g., at Sima del Elefante; Carbonell et al., 2008). Plausibly, the existence in Europe of Mode I technology at the time of Mode II technology in Africa reflects cultural drift under low demographic density conditions that limited the maintainance and transmission of highly sophisticated Mode II techniques in sparsely populated environments (Lycett and von Cramon-Taubadel, 2008). Our survey is focused primarily on sites with magnetostratigraphy and correlations with a reference astronomical time scale that incorporates geomagnetic polarity reversals and/or radiometric dates based on established methods ( $\mathrm{K}-\mathrm{Ar}$ or the more accurate $\mathrm{Ar}-\mathrm{Ar}$ dating) when provided with basic details on the laboratory procedures followed (Ludwig and Renne, 2000). We also discuss sites dated with relatively new types of exposure dating (see a critical review by Ludwig and Renne, 2000), and using mammalian biozonations.

A further motivation for this assessment of early hominin sites is the continued development of new information on the evolution of the Po Valley of northern Italy, which was studied using drill cores distributed from Venice in the east (Kent et al., 2002) to Pianengo near Milan in the west (Muttoni et al., 2003; Scardia et al., 2006) as well as from the adjacent Southern Alps margin at Leffe (Muttoni et al., 2007) and Bagaggera (Scardia et al., 2010) (Fig. 1). These extensive studies of climate, faunal, floral, and sea level changes constrained to the late Early Pleistocene by magnetostratigraphy suggest that the Po Valley may have acted as an important migration gateway to southern Europe at the inception of major northern hemisphere glaciations. We therefore turn our attention in the second part of the paper to the geologic and climatic record of critical areas of northern Africa and the Mediterranean region where hominins (and mammals in general) may have transited from Africa and/or western Asia to southern
Europe. Based on this knowledge, we formulate a testable hypothesis on the timing, pathways, and potential environmental causes of mammal and hominin immigration to southern Europe that is consistent with (or at least not contradicted by) what we would regard as the best-dated archeological record from the literature.

\section{Chronology of early hominin presence in southern Europe}

Magnetostratigraphy is frequently applied to date sedimentary sequences containing hominin remains or artifacts. The method consists in retrieving, with appropriate laboratory techniques, the sequence of polarity reversals registered in rocks by suitable ferromagnetic minerals for correlation with the reference geomagnetic polarity time scale. As for any analytical technique, a magnetostratigraphic study should meet some fundamental quality criteria in order to yield reliable age data, as summarized recently by Langereis et al. (2010). For example, samples should be collected in continuous stratigraphic context and all of them should be fully treated in the laboratory by applying demagnetization techniques that demonstrably include vector subtraction. The minerals responsible for the magnetic remanence should be determined, and no systematic correlation between magnetic mineralogy and polarity should be observed. Ancillary sections to test the lateral reproducibility of polarity intervals should accompany a reference magnetostratigraphic section, if possible. Polarity stratigraphy should be erected using the latitude of the virtual geomagnetic pole calculated for each sample's characteristic magnetic component plotted as function of stratigraphic horizon. All the above should be clearly described and illustrated in accessible publications.

With these basic criteria in mind, we review the published literature on early hominin sites from southern Europe; key dates for this discussion are the ages of the Pleistocene astronomical time scale of Lourens et al. (2004). These ages are essentially the same, within the resolution of polarity transition durations of typically $5 \mathrm{kyr}$ 
(Clement, 2004), as in the geomagnetic polarity time scale since Cande and Kent (1995) adopted in the geologic time scale of Berggren et al. (1995). The key ages are (Fig. 2):

- Brunhes-Matuyama boundary (beginning of C1n) $=0.781 \mathrm{Ma}$

- Matuyama-Jaramillo boundary (beginning of C1r.1r) =0.988 Ma

- Jaramillo-Matuyama boundary (beginning of C1r.1n) =1.072 Ma

- Matuyama-Cobb Mountain boundary (beginning of C1r.2r)= $1.173 \mathrm{Ma}$

- Cobb Mountain-Matuyama boundary (beginning of C1r.2n)= $1.185 \mathrm{Ma}$

- Matuyama-Olduvai boundary (beginning of C1r.3r) $=1.778 \mathrm{Ma}$

- Olduvai-Matuyama boundary (beginning of $\mathrm{C} 2 \mathrm{n}$ ) $=1.945 \mathrm{Ma}$

Until very recently, the beginning of the Pleistocene was placed near the top of the Olduvai $(\sim 1.78 \mathrm{Ma})$ but more germane to this discussion is that the Early Pleistocene is usually considered to extend up to the base of the Brunhes $(0.78 \mathrm{Ma})$, the youngest chron of predominantly normal polarity that includes the Middle and Late Pleistocene (Lourens et al., 2004). Thus, geologic formations regarded as Pleistocene that have a stable reverse polarity magnetization can be considered most probably older than $0.78 \mathrm{Ma}$, i.e., Early Pleistocene. Magnetostratigraphy in such a context is an extremely valuable dating tool although further evidence is needed to restrict the reverse magnetizations to a particular interval of the Matuyama. On the other hand, there is ambiguity with stable normal polarity magnetization, even when there is a stratigraphic upward succession of reverse to normal polarity, because the normal polarity can represent either the Brunhes or the Jaramillo normal polarity (sub)chron [the very short $(\sim 10 \mathrm{kyr})$ Cobb Mountain normal polarity subchron is rarely expected to be encountered especially in discontinuous continental sections]; independent evidence for Early Pleistocene attribution is needed. A stratigraphic upward succession of normal to reverse polarity magnetozones would imply Early Pleistocene but other evidence or arguments are needed to distinguish between the JaramilloMatuyama from the much older Olduvai-Matuyama transition. Reversal excursions are generally too short or ephemeral to be useful for reliable correlations (e.g., Langereis et al., 1997).

\subsection{Italy}

\subsubsection{Ceprano and Fontana Ranuccio}

A hominin cranium from Ceprano, Italy (Ascenzi et al., 1996, 2000; Bruner and Manzi, 2007) (Fig. 1) has been commonly regarded as representative of one of the oldest hominins in Europe (e.g., Dennell, 2008) and considered by Manzi (2004) to be associated with the Brunhes-Matuyama polarity chron boundary ( $0.78 \mathrm{Ma})$, although no direct paleomagnetic evidence was available to support the interpretation. However, new paleomagnetic data from two long cores drilled at Ceprano show no evidence for reverse polarity magnetizations down to $45 \mathrm{~m}$ below the hominin level (Muttoni et al., 2009). Taking into account available $\mathrm{K}-\mathrm{Ar}$ age constraints from the region, this study indicated an age of around $0.45 \mathrm{Ma}(+0.05,-0.1 \mathrm{Ma})$, or Middle Pleistocene and well up in the Brunhes normal polarity chron, for the hominin level at Ceprano (Fig. 2). Evidence for the BrunhesMatuyama boundary was found at Fontana Ranuccio but well below $(\sim 40 \mathrm{~m})$ the level that yielded hominin teeth and a Mode II tool industry (Muttoni et al., 2009), in agreement with a $\mathrm{K}-\mathrm{Ar}$ leucites age of $\sim 0.46 \pm 0.01 \mathrm{Ma}$ reported for this level (Biddittu et al., 1979) (Fig. 2).

\subsubsection{Cà Belvedere}

At Cà Belvedere (Monte Poggiolo) in northern Italy (Fig. 1), Mode I knapped pebbles (Bisi et al., 1992; Villa, 2001; Peretto, 2006) were recovered from a $\sim 4 \mathrm{~m}$-thick sequence of sandy gravels overlain by a soil horizon and resting unconformably on the Pliocene-Pleistocene
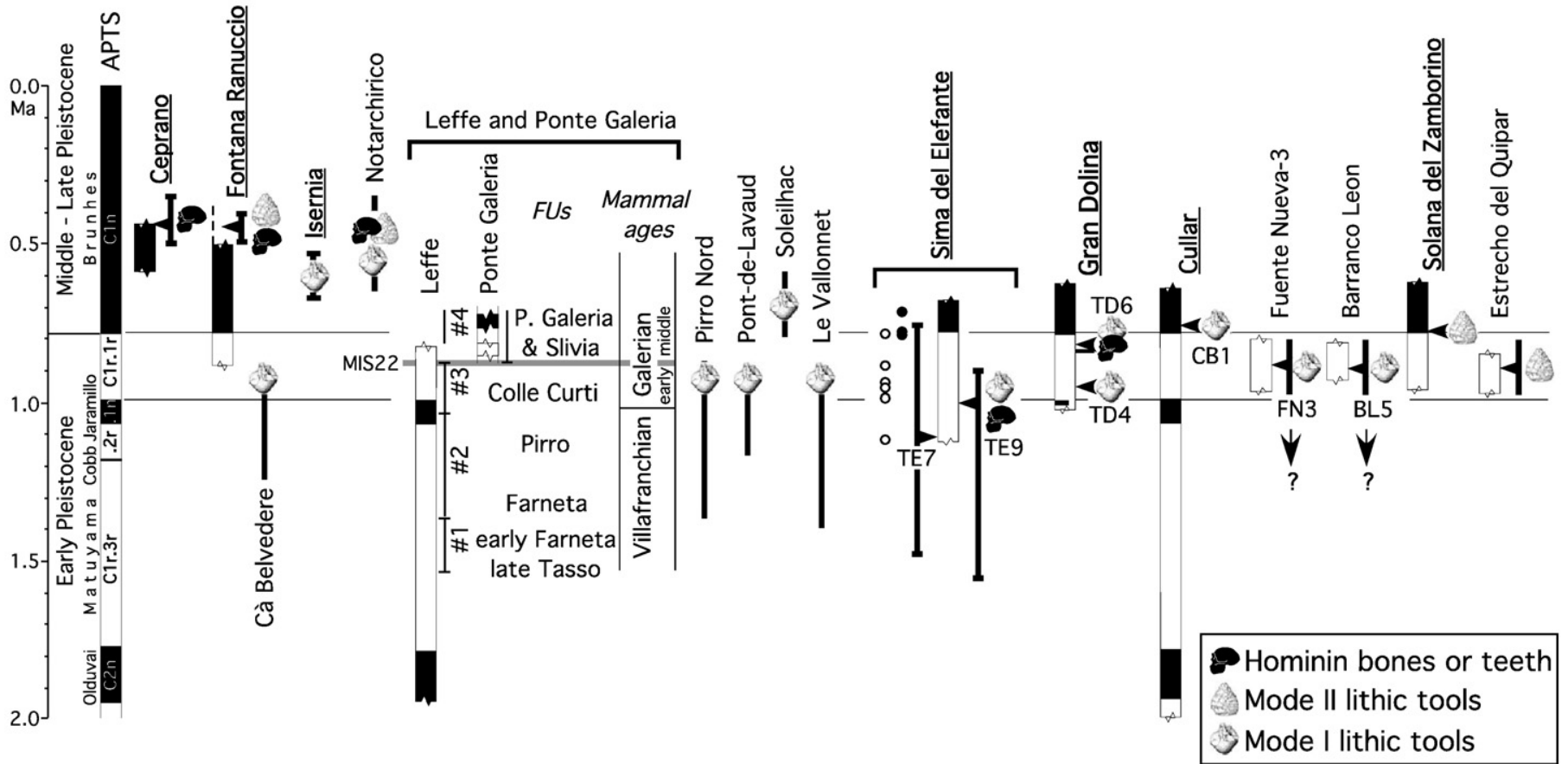

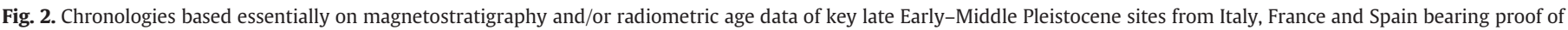

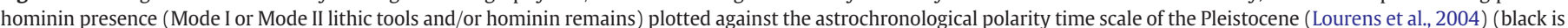

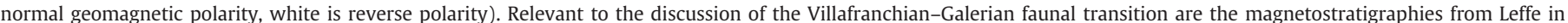

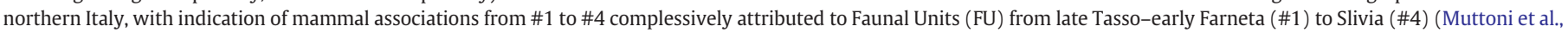

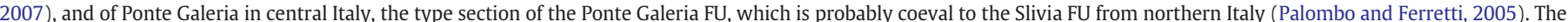

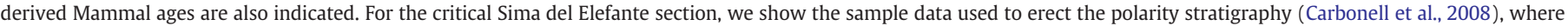

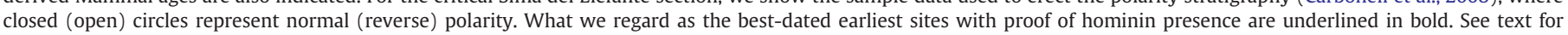
discussion. 
marine to infralittoral Argille Azzurre Formation (Antoniazzi et al., 1992; Gagnepain et al., 1992). Paleomagnetic analyses on 40 samples stratigraphically distributed through the soil horizon and the underlying tool-bearing sandy gravels (Gagnepain et al., 1992) found evidence of north-directed and downward-pointing magnetizations in 32 consecutive samples from the soil horizon to the lower part of the sandy gravels, followed below by three samples with south-directed and upward-pointing magnetizations with inclinations of $-10^{\circ}$ to $-20^{\circ}$. Five additional samples with highly dispersed downward-pointing magnetizations were reported from the base of the tool-bearing sandy gravels.

Despite the occurrence of magnetizations almost exclusively oriented north-and-down (normal polarity), Gagnepain et al. (1992) speculated that the original magnetizations were in fact acquired during a reverse polarity interval (attributed to the Matuyama Chron, $>0.78 \mathrm{Ma}$ ) but in all but three samples, these original magnetizations were entirely overprinted by normal polarity magnetizations during successive and pervasive pedogenic alteration processes. Three electron spin resonance (ESR) dates on quartz grains indicated an average age of $1.065 \pm 0.165 \mathrm{Ma}$ for the sandy gravels (Peretto et al., 1998; see also Villa, 2001 and Bahain et al., 2007), which would place the tool-bearing sandy gravels of Cà Belvedere in a time window comprised between 0.9 and $1.23 \mathrm{Ma}$, which is largely dominated by reverse polarity (late Matuyama Chron) even though virtually only normal polarity magnetizations were found throughout the sampled unit. We therefore provisionally place Cà Belvedere in the late Matuyama around $1 \mathrm{Ma}$ (Fig. 2), based largely on the ESR dates, which are known to have significant uncertainties (Ludwig and Renne, 2000), and stress the need of more definitive paleomagnetic data.

\subsubsection{Isernia}

At La Pineta near Isernia (Fig. 1), Mode I lithic tools (Villa, 2001; Peretto, 2006) were found in levels immediately below a tuff level dated by K-Ar to $0.73 \pm 0.04 \mathrm{Ma}$ (Coltorti et al., 1982 ; mineral used for analysis not specified). This age was supported by a biotite $\mathrm{K}-\mathrm{Ar}$ date of $0.73 \pm 0.07 \mathrm{Ma}$ from a second tuff level from the nearby section of Belfiore, traced $\sim 5 \mathrm{~m}$ above the tool-bearing layers at La Pineta by means of lithostratigraphy (Coltorti et al., 1982). Paleomagnetic analyses were conducted at La Pineta showing the presence of 'clearly reverse' to 'possibly reverse' to 'indeterminate' magnetic polarities such that the section was attributed to the Matuyama Chron, in broad agreement with the $\mathrm{K}-\mathrm{Ar}$ dates, but no details on the paleomagnetic procedures were provided (Coltorti et al., 1982). Recent sanidine ArAr dates of $0.610 \pm 0.01 \mathrm{Ma}$ and $0.606 \pm 0.072$ Ma have been obtained at La Pineta from a tuff level located immediately above the toolbearing layers and virtually coincident with the level previously dated by $\mathrm{K}-\mathrm{Ar}$ to $0.73 \pm 0.04 \mathrm{Ma}$ (Coltorti et al., 2005). This new date would place La Pineta well into the Brunhes normal polarity chron and is at odds with the 'clearly reverse' paleomagnetic interpretation by Coltorti et al. (1982). In this respect, Coltorti et al. (2005) reported that 'the palaeomagnetic investigations revealed that the magnetic polarity underwent a major change from negative in the part of the section below the first occupation layers, to positive in the layers overlying the occupation layer'. Again, however, no details on the paleomagnetic procedures were provided in support of this inference. Therefore, we place La Pineta at $~ 0.6 \mathrm{Ma}$ (Fig. 2) on the strength of the recent $\mathrm{Ar}-\mathrm{Ar}$ date but regard the magnetic characterization as incomplete and ambiguous.

\subsubsection{Notarchirico}

The $\sim 6 \mathrm{~m}$-thick sedimentary succession of Notarchirico in southern Italy (Fig. 1) contains at least nine archeological levels, which yielded Mode I lithic tools alternating with Mode II lithic tools, as well as a hominin femur (Villa, 2001). Thermoluminescence (TL) analyses on quartz grains from the sedimentary succession yielded a contradictory range of dates whereby the oldest date falls stratigra- phically above a younger one (Villa, 2001). Nonetheless, Villa (2001) presents an argument that some of these TL dates are reliable, noticing that the one at $0.640 \pm 0.07 \mathrm{Ma}$ is virtually coincident with an $\mathrm{Ar}-\mathrm{Ar}$ age of $0.654 \pm 0.011$ Ma reported (as a personal communication by J.P. Raynal) for a tephra level from the nearby Vulture volcanic complex, which according to geochemical data is present also in primary depositional context within the tool-bearing sequence at Notarchirico. The picture is complicated somewhat by an age of $0.359(+0.154$, $-0.097)$ Ma obtained on the hominin femur by the uranium-series disequilibrium method (Villa, 2001). Although the precise age of the Notarchirico tool-bearing sequence is unclear, the available evidence would place it no older than within the Brunhes normal polarity chron, to a time span broadly comprised between 0.36 and $0.65 \mathrm{Ma}$ (Fig. 2), although there are no paleomagnetic data to confirm (or refute) this.

\subsubsection{Pirro Nord}

The Pirro Nord karst fissure fills from Apulia in southern Italy (Fig. 1) yielded three cores and six flakes made of flint and characterized by scar geometries considered incompatible with those produced naturally in geofacts (Arzarello et al., 2007). These tools were attributed to a Mode I industry and were found in association with large and small mammal remains pertaining to the Pirro Faunal Unit (FU) (Arzarello et al., 2007). The Pirro FU is placed between 1.3 and $1.7 \mathrm{Ma}$ in virtually all Italian mammal biochronologies (e.g., Gliozzi et al., 1997; Breda and Marchetti, 2005; Palombo and Mussi, 2006; Sardella et al., 2006; Palombo and Sardella, 2007; Masini and Sala, 2007). However, none of the localities that collectively define the Pirro FU is provided with direct radiometric age estimates or paleomagnetic analyses (Napoleone et al., 2003; contra Arzarello et al., 2007). The age of the Pirro FU is primarily based on the inference that it should be younger than the Olivola and Tasso FUs, which were magnetostratigraphically calibrated as occurring close to the OlduvaiMatuyama boundary (1.78 Ma) at localities in the Upper Valdarno of central Italy (Torre et al., 1993; Napoleone et al., 2001; Fig. 1), and older than the Colle Curti FU, magnetostratigraphically calibrated to the base of the Jaramillo subchron (1.07 Ma) at the type locality of Colle Curti in central Italy (Coltorti et al., 1998; Fig. 1). The quality of the magnetostratigraphic study on the sedimentary succession at Colle Curti is, however, difficult to evaluate because no demagnetization data were illustrated and discussed despite the indication of pervasive normal polarity remagnetizations associated with iron sulphides (Coltorti et al., 1998). We notice, moreover, that exclusively normal polarity was found by Giraudi et al. (2003) throughout the whole stratigraphic succession at Castagnone in northwestern Italy (Fig. 1) that straddles a Messinian to mid-Pleistocene time interval known to encompass $\sim 25$ polarity reversals (Berggren et al., 1995; Lourens et al., 2004), casting serious doubt on the primary nature of the magnetic remanence. Nonetheless, the Castagnone locality yielded a small mammal association attributed to the Colle Curti FU, retrieved from levels with normal paleomagnetic polarity ascribed to the Jaramillo subchron (Giraudi et al., 2003).

In a magnetostratigraphic study on the Leffe lacustrine sequence from northern Italy (Muttoni et al., 2007) (Fig. 1), a large mammal association (\#2, with Pachycrocuta brevirostris, Stephanorhinus ex gr. etruscus, Pseudodama eurygonos, and Cervalces cf. carnutorum) compatible with the Pirro FU was described from levels coeval to and older than the Jaramillo subchron. This assemblage was succeeded by a large mammal association (\#3, with Mammuthus meridionalis vestinus, Megaloceros verticornis, and Megaloceros sp.) compatible with the Colle Curti FU from levels coeval to and younger than the Jaramillo subchron, with the top of this association placed at an unconformity correlated to MIS 22 at $0.87 \mathrm{Ma}$ (Fig. 2; the significance of this unconformity and of the overlying mammal association \#4 are described in Section 3). According to data from Leffe, therefore, the Pirro FU-Colle Curti FU transition could be placed within the Jaramillo at $\sim 1$ Ma rather than 
below the Jaramillo at 1.3 Ma as proposed by Arzarello et al. (2007) based on uncalibrated mammal chronologies from the literature (e.g., Gliozzi et al., 1997; Masini and Sala, 2007). Hence, the lithic artifacts from Pirro Nord may be as young as the upper age limit of the Pirro FU at Leffe at $\sim 1 \mathrm{Ma}$ (Fig. 2), provided that the faunal unit is in fact isochronous over this geographic range.

\subsection{France}

Following the compilation of Carbonell et al. (2008), we discuss the chronostratigraphy of the following sites with lithic tools from France.

\subsubsection{Pont-de-Lavaud}

This site is located on the northern side of the Massif Central (Fig. 1) and yielded Mode I lithic tools from alluvial deposits of Formation D, located $90 \mathrm{~m}$ above the modern valley floor of the Creuse River (Despriée and Gageonnet, 2003; Carbonell et al., 2008 and references therein). Ten ESR analyses on bleached sedimentary quartz samples from Formation D yielded an average ESR age of $1.07 \pm$ 0.09 Ma (Despriée et al., 2006; Bahain et al., 2007 and references therein). These data are reminiscent of very similar ESR dates from Cà Belvedere (Italy) and would place the lithic artifacts from Pont-deLavaud before the Brunhes-Matuyama boundary in a time window (0.98-1.16 Ma) straddling the Jaramillo subchron (Fig. 2). However, neither magnetostratigraphic nor more conventional radiometric age data are thus far available to confirm this age attribution.

\subsubsection{Soleilhac}

At Soleilhac in Haute-Loire, France (Fig. 1), Mode I lithic tools were found in a 1-2 m-thick level of gray silts and sands termed bed $C$ pertaining to a lacustrine succession contained in a maar depression (Thouveny and Bonifay, 1984; Carbonell et al., 2008 and references therein). Two long cores drilled near the archeological site were studied for magnetostratigraphy (Thouveny and Bonifay, 1984). The lower part of bed $\mathrm{E}$ (base of the lacustrine succession, comprised of blue clays and pyroclastics) showed scattered paleomagnetic directions after alternating field demagnetization whereas thermal demagnetization revealed the presence of reverse or intermediate directions. The top of bed $\mathrm{E}$ and the overlying bed $\mathrm{D}$ (lacustrine silts and sands) showed stable normal polarity magnetizations. Toward the top of the cores, above bed B, two samples at $5.2 \mathrm{~m}$ depth showed reverse directions, two samples at $5 \mathrm{~m}$ depth showed intermediate magnetizations, and, finally, two samples at $3 \mathrm{~m}$ depth showed normal magnetizations. Thouveny and Bonifay (1984) inferred that the Soleilhac lacustrine succession recorded a virtually continuous reverse-normal-reverse-normal polarity sequence, with the lithic tool-bearing level contained in the lower normal polarity interval. This normal polarity interval was interpreted as the Jaramillo subchron based on a comparison between the Soleilhac fauna and the fauna from the Italian locality of Isernia (discussed above). The Isernia fauna was considered somewhat more evolved (i.e., younger) than the fauna from Soleilhac, and because the Isernia fauna was placed close to the Brunhes-Matuyama boundary based on the old K-Ar age of $0.73 \pm 0.04 \mathrm{Ma}$ of Coltorti et al. (1982), the supposedly normal polarity interval of the seemingly older Soleilhac fauna was attributed to the Jaramillo subchron (Thouveny and Bonifay, 1984). However, as discussed above, the Isernia site has been recently redated by means of Ar-Ar to $0.6 \mathrm{Ma}$ which would be well into the Brunhes (Coltorti et al., 2005). Moreover, according to Raynal et al. (2001), a pumice ash-fall layer in the lacustrine succession below the archeological bed $\mathrm{C}$ at Soleilhac is correlative to a pumice layer from the nearby locality of Neschers dated by means of $\mathrm{Ar}-\mathrm{Ar}$ to $0.58 \pm$ $0.02 \mathrm{Ma}$ (Lo Bello et al., 1987). Given these uncertainties (coupled with insufficient information on the experimental procedure used to erect the polarity stratigraphy at Soleilhac), the new date of $\sim 0.6 \mathrm{Ma}$ for the Isernia fauna as well the date of $\sim 0.58 \mathrm{Ma}$ for the Neschers pumice suggest that the lithic artifacts from Soleilhac may be younger than the Brunhes-Matuyama boundary (Fig. 2).

\subsubsection{Le Vallonnet}

The Le Vallonnet cave in the Alpes-Maritimes of southern France (Fig. 1) yielded abundant Mode I lithic tools (Bernal and Moncel, 2004; Carbonell et al., 2008 and references therein) and mammal remains (but no hominins) as extensively described by De Lumley (1988) (see also Bernal and Moncel, 2004; Echassoux, 2004; Moullé et al., 2006). De Lumley (1988) dated the cave deposits to 0.98-0.91 Ma based on their Epivillafranchian mammal association. The cave deposits are enclosed between an upper and a lower stalagmitic floor; the base of the upper stalagmitic floor yielded an ESR age of $0.91 \pm 0.06 \mathrm{Ma}$, whereas the top of the lower stalagmitic floor yielded an ESR age of $1.37 \pm 0.12 \mathrm{Ma}$ (Yokoyama et al., 1988). Yokoyama et al. (1988) also reported normal polarity directions from level III of the cave stratigraphy, which they interpreted as pertaining to either the Brunhes or the Jaramillo or the Olduvai, but without illustrating any data or providing any information on the experimental procedure used to obtain the polarity stratigraphy. Gagnepain (1996, unpublished doctoral thesis) provided inconclusive paleomagnetic data from Le Vallonnet, which, as he stated, 'did not allow to establish a clear magnetic polarity for the succession'. Nevertheless, the Le Vallonnet cave deposits are still often attributed to the Jaramillo subchron (e.g., Bernal and Moncel, 2004; Echassoux, 2004; Moullé et al., 2006). Leaving aside the elusive Jaramillo possibility, we retain a generic ESR age window of $\sim 0.9-1.4 \mathrm{Ma}$ for the tool-bearing deposits at Le Vallonnet (Yokoyama et al., 1988; but see Ludwig and Renne, 2000) (Fig. 2) and stress that neither convincing magnetostratigraphic nor more conventional radiometric age data are thus far available to confirm this age attribution.

\subsection{Spain}

The clearest evidence of hominin presence in Europe in the Early Pleistocene (i.e., before the Brunhes-Matuyama boundary) surely comes from magnetostratigraphic studies on classic localities from Spain at Atapuerca (Sima del Elefante and Gran Dolina) and in the Guadix-Baza Basin.

\subsubsection{Gran Dolina (Atapuerca)}

The Gran Dolina karst fissure fills (Fig. 1) was the discovery site for convincing evidence of Early Pleistocene hominins in Europe that yielded several hominin remains and Mode I lithic tools from stratigraphic unit TD6, as well as additional Mode I lithic tools from the underlying unit TD4 (Carbonell et al., 1995). Both stratigraphic units yielded reverse polarity directions and are located just below a well-defined upper normal-lower reverse paleomagnetic polarity transition interpreted as the Brunhes-Matuyama boundary (Parés and Pérez-Gonzalez, 1995, 1999). One sample from the section base yielded a normal polarity direction that was tentatively attributed to the Jaramillo subchron (Parés and Pérez-Gonzalez, 1995, 1999). Recent TL dates are consistent with biostratigraphic and paleomagnetic data and would indicate a probable numeric age of $\sim 0.9-0.95 \mathrm{Ma}$ for the oldest hominin remains at Gran Dolina (Berger et al., 2008). Hence, the available age constraints place the hominin remains at Gran Dolina before the Brunhes-Matuyama boundary but most likely after the Jaramillo subchron (Fig. 2).

\subsubsection{Sima del Elefante (Atapuerca)}

In the Sima del Elefante karst fissure fills (Fig. 1), Parés et al. (2006) found a paleomagnetic polarity reversal interpreted as the BrunhesMatuyama boundary, with the lowermost Mode I tool bearing levels within reversely magnetized strata attributed to the Matuyama Chron. In a subsequent study, Carbonell et al. (2008) confirmed and 
expanded the results of Parés et al. (2006) and reported Mode I lithic tools and a hominin mandible from level TE9 within reverse polarity strata lying below normal polarity strata interpreted as the Brunhes Chron. In addition, two samples were studied for cosmogenic $\mathrm{Al} / \mathrm{Be}$ burial dates; level TE9 provided a burial age of $1.22 \pm 0.16 \mathrm{Ma}$, whereas level TE7 (with no hominin evidence) located $\sim 1.5 \mathrm{~m}$ below provided a burial age of $1.13 \pm 0.18 \mathrm{Ma}$ (Carbonell et al., 2008). The Sima del Elefante level TE9 thus emerges as one of the oldest records of hominin occupation in Europe, attributed an age of 1.1-1.2 Ma on the basis of the cosmogenic burial dates (Carbonell et al., 2008), which would place TE7 and TE9 below the Jaramillo subchron. However, we notice that the Jaramillo was not found, only reverse magnetizations below what was identified as the Brunhes-Matuyama boundary, and that the formal statistical errors for the burial age estimates were quoted at only the $68 \%$ confidence interval whereas at $95 \%$ confidence these data would indicate associated analytical uncertainties of $1.22 \pm$ $0.32 \mathrm{Ma}$ for TE9 and of $1.13 \pm 0.36 \mathrm{Ma}$ for TE7. This would suggest that the uncertainty in the age range of hominin level TE9 is more like 0.9 to $1.54 \mathrm{Ma}$ (and 0.77 to $1.49 \mathrm{Ma}$ in TE7 level below), which would not preclude that hominin occupation at Sima del Elefante occurred sometime between the Jaramillo and the Brunhes-Matuyama boundary (Fig. 2).

\subsubsection{Cúllar}

In the Guadix-Baza Basin near the town of Cúllar (Fig. 1), 5 sections have been correlated into a $\sim 60 \mathrm{~m}$-thick composite section (Agustí et al., 1999). Paleomagnetic analyses have been conducted on the $\sim 15 \mathrm{~m}$-thick lowermost section, revealing the presence of an upper normal-lower reverse polarity transition interpreted as the Brunhes-Matuyama boundary (Agustí et al., 1999). A site named Cúllar Baza-1 with lithic tools (six flakes and two choppers; Roebroeks and van Kolfschoten, 1994) is present in the middle of the $\sim 15 \mathrm{~m}$ thick uppermost section, some $\sim 40 \mathrm{~m}$ above the inferred BrunhesMatuyama boundary and therefore presumably within strata pertaining to the Brunhes Chron, although no paleomagnetic analyses have been carried out to confirm this polarity attribution, which is inferred from lithological correlations with the lower section (Agustí et al., 1999). In a subsequent study, Gibert et al. (2007) reported the magnetostratigraphy of an $\sim 80$ m-thick and continuous Cúllar section located $\sim 2 \mathrm{~km}$ southeast of the 5 sections used by Agustí et al. (1999) to build their composite section. This new section extends from the Olduvai Subchron upward across the Jaramillo Subchron and directly to the tool-bearing Cúllar Baza-1 site (not sampled by Agustí et al., 1999), which was found only $2 \mathrm{~m}$ above the Brunhes-Matuyama boundary within an additional $\sim 17 \mathrm{~m}$ of strata pertaining to the Brunhes Chron. To explain the incongruent position of the Cúllar Baza-1 site with respect to polarity stratigraphy, Gibert et al. (2007) infer that the Brunhes-Matuyama boundary found by Agustí et al. (1999) in their lowermost section occurs at a disconformity whereby the overlying normal polarity strata are Late Pleistocene in age. Following Gibert et al. (2007), we place the tool-bearing Cúllar Baza-1 site in the earliest part of the Brunhes Chron, close to the BrunhesMatuyama boundary (Fig. 2).

\subsubsection{Fuente Nueva-3 and Barranco León}

At these sections from the Velez Valley of the Guadix-Baza Basin near Orce (Fig. 1), levels with Mode I lithic tools are embedded within several meters of section with exclusive reverse polarity attributed to a generic Matuyama Chron (Oms et al., 2000). Oms et al. (2000) had cautiously suggested that these sections might be older than the Jaramillo (i.e., $>1.07 \mathrm{Ma}$ ) based on micromammal biostratigraphy, namely the presence of Allophaiomys burgondiae at Fuentenueva-3. However, A. burgondiae is present in central Italy in the Colle Curti FU (Masini and Sala, 2007) that at Leffe in northern Italy was found to straddle the Jaramillo subchron and extend up to MIS 22 at $0.87 \mathrm{Ma}$ (Muttoni et al., 2007).
In a subsequent study, Scott et al. (2007) assembled the magnetostratigraphies from Fuente Nueva-3 and Barranco León of Oms et al. (2000) with the published magnetostratigraphies from Fuente Nueva-1 and Barranco de Orce that have exclusively reverse polarity (but none with proof of hominin presence), and studied for magnetostratigraphy an additional $\sim 6 \mathrm{~m}$-thick section (Mojona Mine) from the lowest levels in the Velez Valley, where they found exclusively normal polarity (Scott et al., 2007 and references therein). These 5 magnetostratigraphic sections were pieced together by correlation of continental facies (palustrine, alluvial, fluvio-palustrine) producing a normal-reverse composite polarity sequence that is, however, still affected by extensive sampling gaps in the lower part, notably between the Mojona Mine normal polarity interval and the reverse polarity interval of the 4 upper sections. To augment the stratigraphic coverage, Scott et al. (2007) sampled 4 sections in the nearby Salar Valley (none with proof of hominin presence), finding exclusively reverse polarity in 3 sections (Venta Micena, Cañada del Salar, and Camino del Llano) and a reverse-normal-reverse polarity sequence at Rincon de la Losa from the lowest levels in the Salar Valley. These 4 magnetostratigraphic sections were pieced together by correlations of continental facies (palustrine, alluvial, fluviopalustrine) producing a presumably more continuous reversenormal-reverse composite polarity sequence for the Salar Valley, which was correlated again by means of continental facies to the discontinuous Velez Valley polarity sequence, producing a composite reverse-normal-reverse polarity sequence thought to be valid for the Guadix-Baza Basin of the Orce area (Scott et al., 2007). The normal polarity interval was attributed to the Olduvai subchron (1.95$1.77 \mathrm{Ma}$ ) essentially because the mammal faunas from the overlying reverse polarity interval at Fuentenueva- 1 are similar to faunas found at the hominin site of Dmanisi in Georgia, which is dated to around 1.7 Ma or younger (Gabunia et al., 2000). The Guadix-Baza overall composite reverse-normal-reverse polarity sequence was therefore attributed to the Matuyama-Olduvai-Matuyama interval, prior to the Jaramillo Subchron, which was not found, and would imply that the tool bearing levels at Barranco León and Fuente Nueva-3 would now fall between the Olduvai and the (undetected) Jaramillo subchrons at 1.2-1.25 Ma (Scott et al., 2007).

We suggest that physical correlations of strata between the toolbearing Fuente Nueva-3 and Barranco León sections of exclusively reverse polarity and the remainder of the (supposedly coeval) sections of reverse polarity are ambiguous because the embedding palustrine sediments appear to be monotonous and/or laterally discontinuous (see Figs. 2 and 3 in Scott et al., 2007). Hence, it cannot be precluded that the tool-bearing levels lay entirely above and thus could be younger than the Fuente Nueva-1 and Barranco de Orce sections. All that can be said with any confidence concerning the age of the tool bearing levels at Fuente Nueva-3 and Barranco León sections is that they predate the Brunhes-Matuyama boundary (0.78 Ma) and postdate the Olduvai-Matuyama boundary (1.77 Ma), falling either before or after but not during the Jaramillo subchron (Fig. 2).

\subsubsection{Solana del Zamborino and Estrecho del Quipar}

In the $\sim 27$ m-thick Solana del Zamborino fluvio-lacustrine section from the Guadix-Baza Basin (Fig. 1), Scott and Gibert (2009) found convincing evidence for the Brunes-Matuyama boundary, with Mode II lithic tools located immediately above the polarity reversal boundary at a nominal age of $0.77-0.75 \mathrm{Ma}$ (Fig. 2). Estrecho del Quipar in the Guadix-Baza Basin near Caravaca (Fig. 1) yielded Mode II lithic tools and hominin teeth from a $10 \mathrm{~m}$-thick sequence of fine-grained paleosols infilling a relict weathering cavity (rock shelter). Magnetostratigraphic analyses from two sections, encompassing a total of $\sim 6.2 \mathrm{~m}$, indicate the presence of exclusive reverse polarity pertaining to the Matuyama Chron (Scott and Gibert, 2009). Based on the presence of micro-mammals, notably Microtus 
(E)

(F)

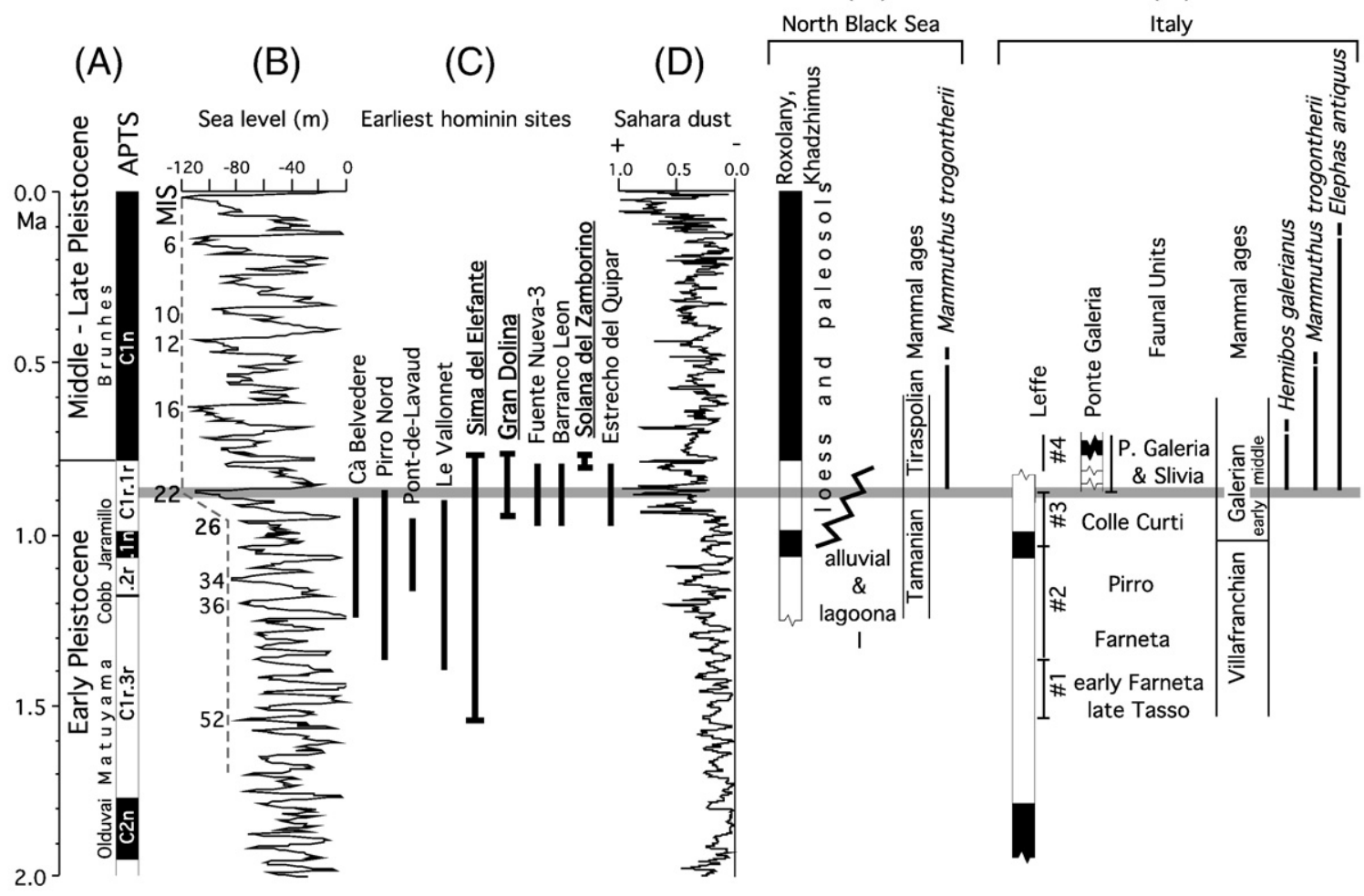

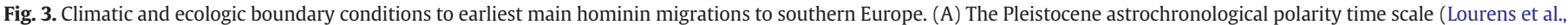

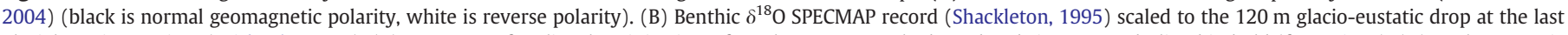

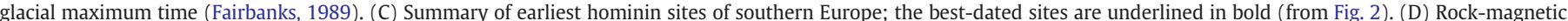

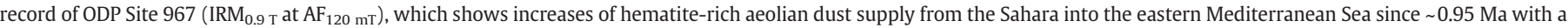

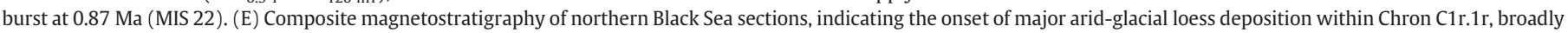

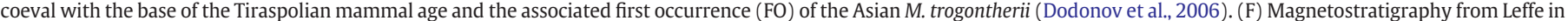

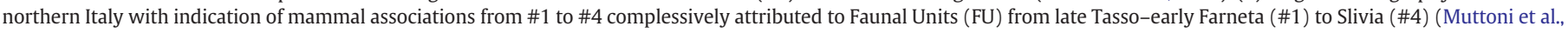

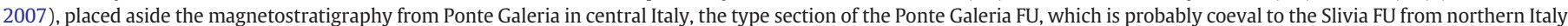

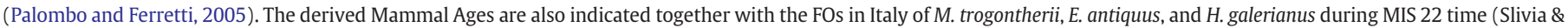
Ponte Galeria FUs).

huescarensis, found at the Huéscar-1 site of the Guadix-Baza Basin within a composite magnetostratigraphic sequence about $10 \mathrm{~m}$ below a polarity reversal interpreted as the Brunhes-Matuyama boundary (Gibert et al., 2007), Scott and Gibert (2009) propose a nominal age of $\sim 0.9$ Ma for the Estrecho del Quipar lithic tools and hominin remains (Fig. 2).

\subsection{Summary}

In summary, we regard the best-dated sites with proof of early hominin presence in southern Europe as (i) Ceprano, Fontana Ranuccio, and Isernia in Italy, complessively dated to $~ 0.35-0.6 \mathrm{Ma}$ within the Middle Pleistocene, (ii) Cúllar Baza-1 and Solana del Zamborino in Spain, virtually coincident with the Brunhes-Matuyama (Early-Middle Pleistocene) boundary ( 0.78 Ma), and (iii) the preBrunhes-Matuyama boundary (Early Pleistocene) sites of Sima del Elefante, broadly dated to $\sim 0.8-1.5 \mathrm{Ma}$, and of Gran Dolina, dated to $\sim 0.99-0.78 \mathrm{Ma}$ (assuming the lower normal polarity interval represents the Jaramillo subchron). Next are Fuente Nueva-3, Barranco León, and Estrecho del Quipar from Spain, which predate the Brunhes-Matuyama boundary (0.78 Ma) and postdate the OlduvaiMatuyama boundary (1.77 Ma), falling either before or after but not during the Jaramillo subchron. The other sites we evaluated are affected by large age uncertainties. The magnetostratigraphic data from Cà Belvedere, Soleilhac, and Le Vallonnet do not meet basic quality criteria, whereas the radiometric ages of several late Early Pleistocene faunal units of the Italian mammal biochronology (e.g.,
Gliozzi et al., 1997) used by Arzarello et al. (2007) at Pirro Nord are poorly known. ESR or similar dating techniques used at Cà Belvedere, Notarchirico, Le Vallonnet, and Pont-de-Lavaud are associated with potential analytical errors of up to $\pm 15-30 \%$ (Ludwig and Renne, 2000; Zhao et al., 2001) or $\pm 10-25 \%$ (Rink et al., 2007), and may not (yet) be suitable as stand-alone dating tools. This is due to several uncertainties including difficulties to determine the correct rate of trapping of electrons stimulated by cosmic and terrestrial radiation, incomplete resetting of the sample's timer by exposure to sunlight (bleaching), and a basic lack of procedure standardization (see the review of Ludwig and Renne, 2000).

Several sites bearing as evidence of early hominins exclusively Mode I lithic tools that have been regarded as suspiciously similar to geofacts have been excluded from our compilation. These include sites from the Massif Central and Haute-Loire of France (Blassac, Chilhac III, Perrier-Etouaires, Saint-Eble, le Coupet, La Roche-Lambert), some associated with ages much older than $1 \mathrm{Ma}$, that yielded 'tools' that most probably have been produced by volcanic processes (Raynal et al., 1995), whereas the only in situ tool from Monte Peglia and some of the artifacts from Colle Marino in central Italy 'look like geofacts' according to Villa (2001). For the reminder of the sites in our compilation bearing only Mode I tools (Isernia, Pirro Nord, Pont-deLavaud, Le Vallonnet, Cúllar Baza-1, Fuente Nueva-3, and Barranco León), we rely on the lack of reported suspicion that they could represent geofacts.

From the above we conclude that the available magnetochronologic data from Italy, France, and Spain indicate that the main earliest 
hominin presence in southern Europe occurred sometime during the Matuyama Chron (before the Brunhes-Matuyama boundary at $0.78 \mathrm{Ma}$ but after the Olduvai-Matuyama boundary at $1.77 \mathrm{Ma}$ ). Within this broad age window, dates of the two best-dated oldest sites (Sima del Elefante and Gran Dolina) overlap within error resolution in the temporal range between the Jaramillo and the Brunhes-Matuyama boundary ( 0.99-0.78 Ma), whereas data from the remaining sites of generic pre-Brunhes-Matuyama boundary age (Fuente Nueva-3, Barranco León, and Estrecho del Quipar) do not contradict the hypothesis of earliest peopling during this age window (Fig. 2). This allowable age window coincides with a most profound climate and faunal turnover known as the late Early Pleistocene revolution, as described below.

\section{Late Early Pleistocene climate and faunal revolution}

Kent et al. (1971) studied ice-rafted detritus in North Pacific deepsea sediment cores with magnetostratigraphy and found evidence of cooling beginning at about $1.2 \mathrm{Ma}$ and becoming very intense between the Jaramillo subchron and the Brunhes-Matuyama boundary (Chron C1r.1r, 0.99-0.78 Ma), and suggested that this interval probably corresponds to the initiation of mid-latitude glaciations of Europe and North America. Shackleton and Opdyke (1976) analyzed planktonic foraminifera $\delta^{18} \mathrm{O}$ data from equatorial Pacific core V28239 with magnetostratigraphy and first identified MIS 22 within C1r.1 $r$ as most likely to represent the first major northern hemisphere continental glaciation of Middle Pleistocene character, whereas prior to MIS 22 global climate was characterized by higher frequency ( $40 \mathrm{kyr})$ and lower amplitude glacial fluctiations extending back through the Olduvai subchron. Berger et al. (1993) used planktonic foraminifera $\delta^{18} \mathrm{O}$ data from ODP Site 806 from the equatorial Pacific and confirmed an abrupt change in global climate variability from $\sim 40 \mathrm{kyr}$ lower-amplitude glacio-eustatic oscillations to $\sim 100 \mathrm{kyr}$ higher-amplitude oscillations between MIS 23 and MIS 22, and introduced the term 'climate revolution' to describe this change. Shackleton (1995) used benthic foraminifera $\delta^{18} \mathrm{O}$ data from ODP Site 677 (SPECMAP) and found a marked change of climate variability silimar to that of Berger et al. (1993) with MIS 22 standing out as the first most prominent cold stage of the Pleistocene. Head and Gibbard (2005) adopted for the critical interval under discussion the same ODP Site 677 (SPECMAP) data of Shackleton (1995) and pointed out the existence of a series of discrete cold events from MIS 36 ( $\sim 1.2 \mathrm{Ma}$ ) to MIS 13 ( 0.54-0.46 Ma) with MIS 22 judged as the first most profound.

From the above, we see that the marked change to higher amplitude in global climate variability occurred broadly between MIS 36 ( 1.2 Ma) and MIS 13 ( 0.54-0.46 Ma) (e.g., Head and Gibbard, 2005; Lisiecki and Raymo, 2005), and that within this transition, MIS 22 at $~ 0.87$ Ma stands out, representing the first major northern hemisphere continental glaciation of the Pleistocene (Shackleton and Opdyke, 1976; Berger et al., 1993; Shackleton, 1995; Lourens et al., 2004) (Fig. 3A, B). This climate transition occurs within Chron C1r.1r, the same magnetochronologic window that we believe includes the best-dated sites with evidence of the earliest peopling of southern Europe (Figs. 2 and 3C).

It is possible that MIS 22 within the late Early Pleistocene global climate transition caused a critical climate change in Africa, the hominin homeland, as well as in Europe that triggered hominin migrations to southern Europe. For example, rock-magnetic data from Ocean Drilling Program Site 967 south of Cyprus (Fig. 1) revealed sudden increases of hematite-rich aeolian dust from the Sahara since $\sim 0.95 \mathrm{Ma}$ with a noticeable burst in dust production and therefore aridity at $0.87 \mathrm{Ma}$ (MIS 22) (Larrasoaña et al., 2003) (Fig. 3D). More recently, Trauth et al. (2009) analyzed published dust flux records from the Arabian Sea, the eastern Mediterranean Sea, and the Atlantic Ocean, and concluded that an increase in aridity started in Africa at $\sim 1.5 \mathrm{Ma}$ and culminated at $\sim 1 \mathrm{Ma}$. Enhanced aridity during this time matched a progressive vegetation shift in sub-Sahara Africa from C3 trees and shrubs to arid-adapted C4 grasses between ca 1.5 and $0.7 \mathrm{Ma}$ as evidenced from stable carbon isotope records (Ségalen et al., 2007). At about the same time, the onset of deposition of arid-glacial loess occurred across the lowlands of the northern Black Sea coastal area and the East European plains. Here, magnetostratigraphic studies (e.g., at Roxolany and Khadzhimus near Odessa; Dodonov et al., 2006) place this major facies change mainly in Chron C1r.1r, the reverse polarity interval between the Jaramillo and Brunhes (e.g., Tsatskin et al., 2001; Dodonov et al., 2006; Faustov et al., 2009) (Fig. 3E).

Enhanced aridification in Africa and Eastern Europe during the late Early Pleistocene and notably MIS 22 may have set in motion herds of mammals, possibly including hominins, to more sustainable refugia of southern Europe. Areas of southern Europe like northern Italy or the Apennines of central Italy were also characterized by forest withdrawal and onset of steppe or open vegetation at MIS 22 time (Bertini, 2000; Muttoni et al., 2007). However, climatically favourable refugia located in the southern peninsulas of Iberia, Italy and the Balkans, as well as along the North Africa shores, sheltered a large number of temperate species during Pleistocene glacial periods (e.g., Bennett et al., 1991), and several of these refugia geographically overlap with sites of hominin presence outlined in this study (Carrion et al., 2003; Médail and Diadema, 2009). We should therefore expect to find the first appearance of African and Asian emigrants in southern Europe at about MIS 22 time. An important locality where this prediction can be tested is Leffe in northern Italy (Muttoni et al., 2007). Here, the loess and paleosol levels above a major unconformity correlated to MIS 22 record the first occurrence of Elephas antiquus (mammal association \#4, Fig. $3 \mathrm{~F}$ ), which is regarded as a taxon that immigrated to southern and western Europe from Africa (Lister et al., 2005; Palombo and Ferretti, 2005; see also below). However, the best locality where the entrance in southern Europe of E. antiquus as well as of several other emigrant taxa from Africa and Asia has been studied is the Roman Basin of central Italy, typified by the site of Ponte Galeria (Fig. 1). Here, Ambrosetti et al. (1972) described the presence of an unconformity at the base of the Ponte Galeria Formation corresponding to the so-called Cassian erosional phase dated at around $1 \mathrm{Ma}$ from published radiometric dates. More recent paleomagnetic data indicate reverse polarity (late Matuyama) in the Helicella clays located immediately above the base of the Ponte Galeria Fm. and containing cold-adapted small mammals and molluscs (Kotsakis et al., 1992), and normal polarity (Brunhes) in the overlying Venerupis senescens clays (Kotsakis et al., 1992; Florindo and Marra, 1995). Accordingly, the Cassian unconformity can be correlated to the sea level fall of MIS 22 at $\sim 0.87 \mathrm{Ma}$ (Kotsakis et al., 1992; Florindo and Marra, 1995; Marra et al., 1998; Milli et al., 2004) (Fig. 3F).

The Cassian unconformity marks a turnover from late Villafranchian to middle Galerian faunas, characterized by the appearance of new types of adaptation accompanied by wide-ranging changes in climate and vegetation (Azzaroli, 1983). In particular, the Ponte Galeria FU [as well as the probably equivalent but undated Slivia FU from northeastern Italy (Milli et al., 2004; Palombo and Ferretti, 2005; Raia et al., 2006)] differs from Villafranchian faunas by a general increase in large herbivore richness and a parallel reduction of large predators (Fig. 3F; Palombo and Mussi, 2006), and records the first occurrence in Italy of the African emigrant E. antiquus, previously described at Leffe, as well as of Mammuthus trogontherii and Hemibos galerianus (e.g., Martinez-Navarro and Palombo, 2004; Palombo and Ferretti, 2005; Sardella et al., 2006; Masini and Sala, 2007). Notably, $M$. trogontherii is regarded as a taxon that immigrated to southern and western Europe from Asia and, together with the African emigrant E. antiquus, co-existed with before replacing resident populations of M. meridionalis (Lister et al., 2005; Palombo and Ferretti, 2005), whereas $H$. galerianus is considered an immigrant from India (Martinez-Navarro and Palombo, 2004). 
This faunal renewal is recognized elsewhere in southern Europe, e.g., in Greece (Kostopoulos et al., 2007) and Spain at Huéscar-1 (Fig. 1) where E. antiquus (van der Made and Mazo, 2001) first occurs in levels dating to before the Brunhes-Matuyama boundary (Gibert et al., 2007). Outside southern Europe, MIS 22-related faunal turnovers are also recognized in northwestern Europe (base of Cromerian Complex Stage), Eastern Europe (base of Tiraspolian mammal Stage of Russia) as well as elsewhere in Russia, as summarized by Head and Gibbard (2005 and references therein). In Eastern Europe, the onset of major loess deposition during the Jaramillo subchron and mainly the subsequent Chron C1r.1r essentially coincides with the Tamanian-Tiraspolian faunal turnover and the associated first occurrence in these regions of the Asian emigrant M. trogontherii (Dodonov et al., 2006) (Fig. 3E), which we would place at essentially the same time (together with E. antiquus) in southern Europe at Slivia and Ponte Galeria (Fig. 3F).

In conclusion, there are sound arguments and data to consider the spread in Europe of African and Asian emigrants as characterizing the most important faunal turnover of the late Early Pleistocene, and to place its base ( $=$ base of middle Galerian in Italy = base Cromerian in northwestern Europe = base Tiraspolian in Eastern Europe, etc.) at MIS 22 at $\sim 0.87 \mathrm{Ma}$ (Head and Gibbard, 2005 and references therein).

\section{Migration pathways}

We speculate that profound global environmental changes associated with the late Early Pleistocene climate transition may have driven the migration of large herbivores such as E. antiquus from Africa and $M$. trogontherii from Asia into more habitable southern European refugia (Fig. 3E,F) and this closely coincided with the earliest immigration of hominins (Fig. 3C). A large herbivore-hominin migration wave around MIS 22 time may have left traces in the African and European archeological and geological records. The Danakil depression at the northern end of the East African rift system was a likely staging area for this migration (Fig. 4). Indeed, hominin remains have been found there associated with water-rich environments

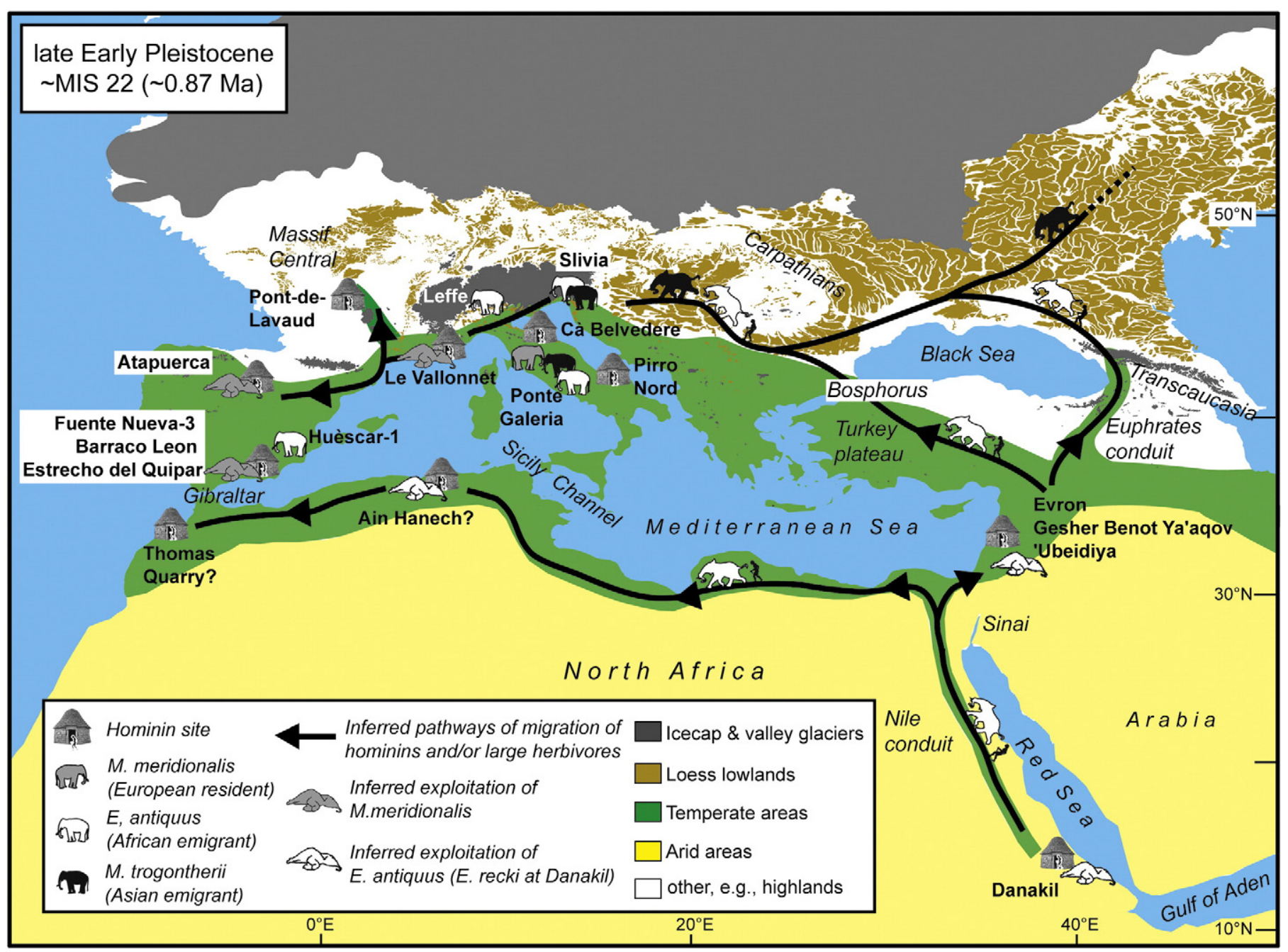

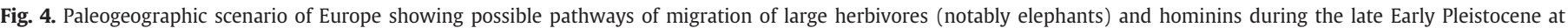

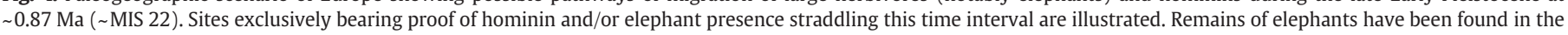

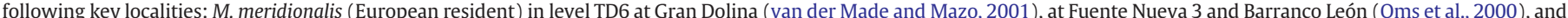

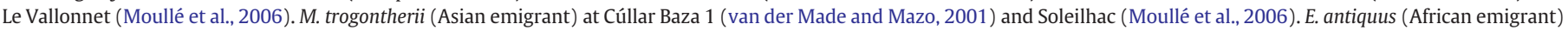

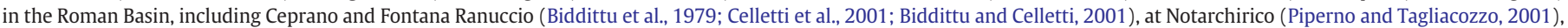

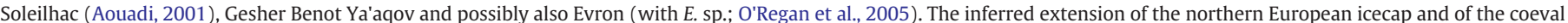

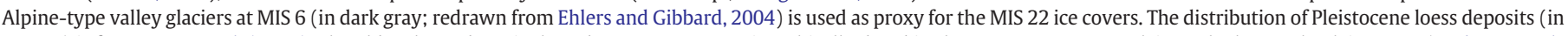

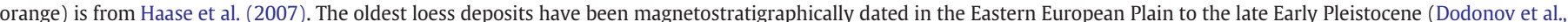

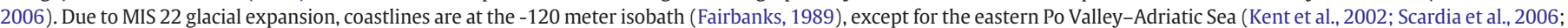

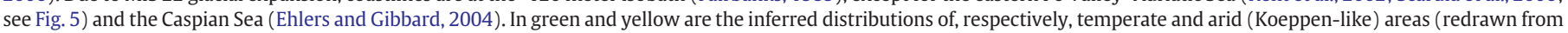
Peel et al., 2007). 
(Martinez-Navarro et al., 2004; Abbate et al., 2004) magnetostratigraphically constrained to the Jaramillo-Matuyama boundary (0.99 Ma) (Albianelli and Napoleone, 2004). However, by the time of deposition of the fluvio-deltaic Aro Sand just before the BrunhesMatuyama boundary (Albianelli and Napoleone, 2004) there is no more evidence of hominins or mammals in general (Abbate et al., 2004). From the Danakil, the most likely route across the Saharan desert barrier was through the Nile Valley (Fig. 4) (Derricourt, 2005; Vermeersch, 2006) whose modern drainage system was apparently structured in the late Early Pleistocene possibly around 0.8 Ma (Said, 1993).

From the southern Mediterranean shores [e.g., Ain Hanech in northern Algeria (Sahnouni et al., 2002, 2004; Geraads et al., 2004) and Thomas Quarry in Atlantic Morocco (e.g., Raynal et al., 2002)], potential migration paths to southern Europe are crossings of the Gibraltar Strait and/or the Sicily Channel but these are considered unlikely routes (Derricourt, 2005; Villa, 2001). The Gibraltar Strait has been open to the Atlantic since the end of the Miocene and even highly fluctuating Pleistocene sea levels would not have substantially affected the $\sim 5 \mathrm{~km}$ wide central channel, now $300 \mathrm{~m}$ deep (Derricourt, 2005) and experiencing tectonic uplift since at least the late Pleistocene (Gracia et al., 2008). According to Straus (2001), the chronological and archeological data indicate that it is only in the terminal Paleolithic $(\sim 11 \mathrm{ka})$ that a credible case can be made for trans-Gibraltar human contacts. The routes in and out of Iberia are largely over the Pyrenees and occasional claims for hominin and other mammalian dispersal across the Gibraltar Strait have no convincing evidence to support them (O'Regan, 2008). An even less likely migration route was the Sicily Channel, now $\sim 145 \mathrm{~km}$ wide, which was submerged (albeit possibly reduced to $\sim 1 / 2$ of its present width) even during maximum Pleistocene low-stands based on evidence of mammal endemism indicating that Sicily acted as an archipelago during the Pleistocene (Villa, 2001; Marra, 2005). Moreover, Villa (2001) has shown that Middle Pleistocene settlement of Italy came from the north and not via Sicily-northern Africa.

More plausibly, hominins and large herbivores migrated from Africa by land via the Sinai corridor (Derricourt, 2005) into the Levant, marked by a convincing hominin presence in the Early Pleistocene at Gesher Benot Ya'aqov (Goren-Inbar et al., 2000), Evron (Ron et al., 2003), and 'Ubeidiya (Opdyke et al., 1983; Martinez-Navarro et al., 2009) (Fig. 4). They may have eventually accessed southern Europe through the Bosphorus, which was at least intermittently exposed during the Pleistocene based on a wealth of geophysical and geological data suggesting that throughout the past two million years, the Black Sea was predominantly a freshwater lake (Ryan et al., 2003). Alternatively, large mammals and hominins may have exploited a route through a paleo-Euphrates conduit into Transcaucasia and, from there, into the lowlands of the northern Black Sea coastal area. Both routes (Bosphorus and Euphrates) seem viable considering that lower Paleolithic tools have been found throughout Turkey including the Marmara region, as well as in the Euphrates river basin (Kuhn, 2002). Notably, most of the fluvial terraces in the Euphrates river basin are interpreted as dating from the late Early Pleistocene onwards, and these terraces often contain lithic artifacts (Demir et al., 2007).

From the lowlands of Eastern Europe or the northern Black Sea coastal area, migration routes were possibly westward along a Danube corridor into the northern Adriatic area and the Po Valley of northern Italy and from there along coastal routes to southern Italy and across the Maritime Alps and the Pyrenees into Spain (Fig. 4). Alternative migration routes to southern Europe passing across Central Europe to the north of the Alpine glaciated area are less favored considering the harsher expected climate closer to the Fennoscandian ice sheet during the prominent cold stage of MIS 22 ( $\sim 0.87 \mathrm{Ma}$ ). It is possibly not until post-MIS 22 interglacials that there is evidence of hominins venturing as far north as Pakefield in the UK
(Parfitt et al., 2005, 2010; Lee et al., 2006). (See 'Note Added in Proof at the end of paper').

It is thus possible that the Po Valley was a viable migration gateway to southern Europe during the late Early Pleistocene. The Po Valley consequently deserves special attention, especially considering the large amount of new data becoming available that bear on its climatic and geologic evolution during the Pleistocene.

\section{The Po Valley gateway}

The Po Valley represents one of the best-studied areas for climatedriven changes in style of deposition occurring at MIS 22 within Chron C1r.1r, when a drastic reorganization of vegetation and fluvial drainage patterns occurred at the onset of major Pleistocene glaciations in the Alps. Enhanced cooling at this time is reflected by a generalized event of forest withdrawal and strong progradation and aggradation of alluvial fan bodies from the Southalpine margin towards the Po Valley. In intermountain basins like Leffe (Fig. 5A,B), this massive pulse of alluvial fan progradation terminated a long history of Early Pleistocene lacustrine sedimentation with a major unconformity at around MIS 22 time (Muttoni et al., 2007). At the foothills of the Southern Alps, these pulses of alluvial fan progradation resulted in valley damming and lake formation (Scardia et al., 2010). More southward in the Po Valley, a major shift from mainly meandering to exclusively braided fluvial systems occurred at this time. This shift in style of deposition is recorded by a regional unconformity termed the ' $R$ surface' that was seismically traced in the subsurface across much of the Po plain and its age constrained magnetostratigraphically in several cores (e.g. Pianengo, Ghedi; Fig. 5A, B) to MIS 22 (Muttoni et al., 2003, 2007; Scardia et al., 2006, 2010) (Fig. 3F). More eastward in the Adriatic Sea, the ' $R$ surface' seems to correlate to the onset of progradation of basinal turbidites onto a previously starved slope setting, occurring (shortly) before the Brunhes-Matuyama boundary in the Venice core (Kent et al., 2002; Massari et al., 2004; Fig. 5A, B). At MIS 22 during Chron C1r.1r, Alpine valley glaciers reached the Po Valley apparently for the first time, as testified by the reverse polarity magnetization of (glacio)lacustrine deposits associated with the early stages of building of the Ivrea (Carraro et al., 1991), Iseo (Scardia et al., 2006), and Garda (Cremaschi, 1987) morainic amphitheatres (Fig. 5B). Increasing rates of erosion during the waxing and waning of major Alpine valley glaciers starting at MIS 22 time (and including the subsequent particularly dry and cold MISs 16, 12, 6, and 2; Kukla and Cilek, 1996) determined also the onset of a long-term phase of isostatic uplift in the southern Alps (Scardia et al., 2006), western and central Alps (Champagnac et al., 2007, 2009), as well as possibly in other glaciated mountain chains of Europe and Asia (Kukla and Cilek, 1996).

In summary, Pleistocene glacial stages starting with MIS 22 at $\sim 0.87 \mathrm{Ma}$ were characterized by enhanced glacier development and glacio-eustatic lowstands, as well as substantial forest withdrawal in the Alpine region. Long phases of persistent low forest cover (steppeforest at low altitudes), coupled with marked base level glacioeustatic falls, promoted physical erosion and the progradation of alluvial fans from the Alps and probably also the Apennines (which consequently experienced long-term isostatic uplift) toward the peripheral plains. Here, sediments were redistributed by braided river systems and ended up in the northern Adriatic Sea as basinal turbidites, as observed in the Venice subsurface. One of the main outcomes of these studies is that the Po Valley was largely submerged as far west as Milan during Early Pleistocene lowstands, whereas it was only since MIS 22 at $~ 0.87$ Ma that large stretches of the Po Valley became more persistently exposed. This may have opened possibly for the first time in the Pleistocene viable new migration routes for large mammals and hominins across northern Italy to southern France and Spain in the west (Figs. 4 and 5B). 
(A)

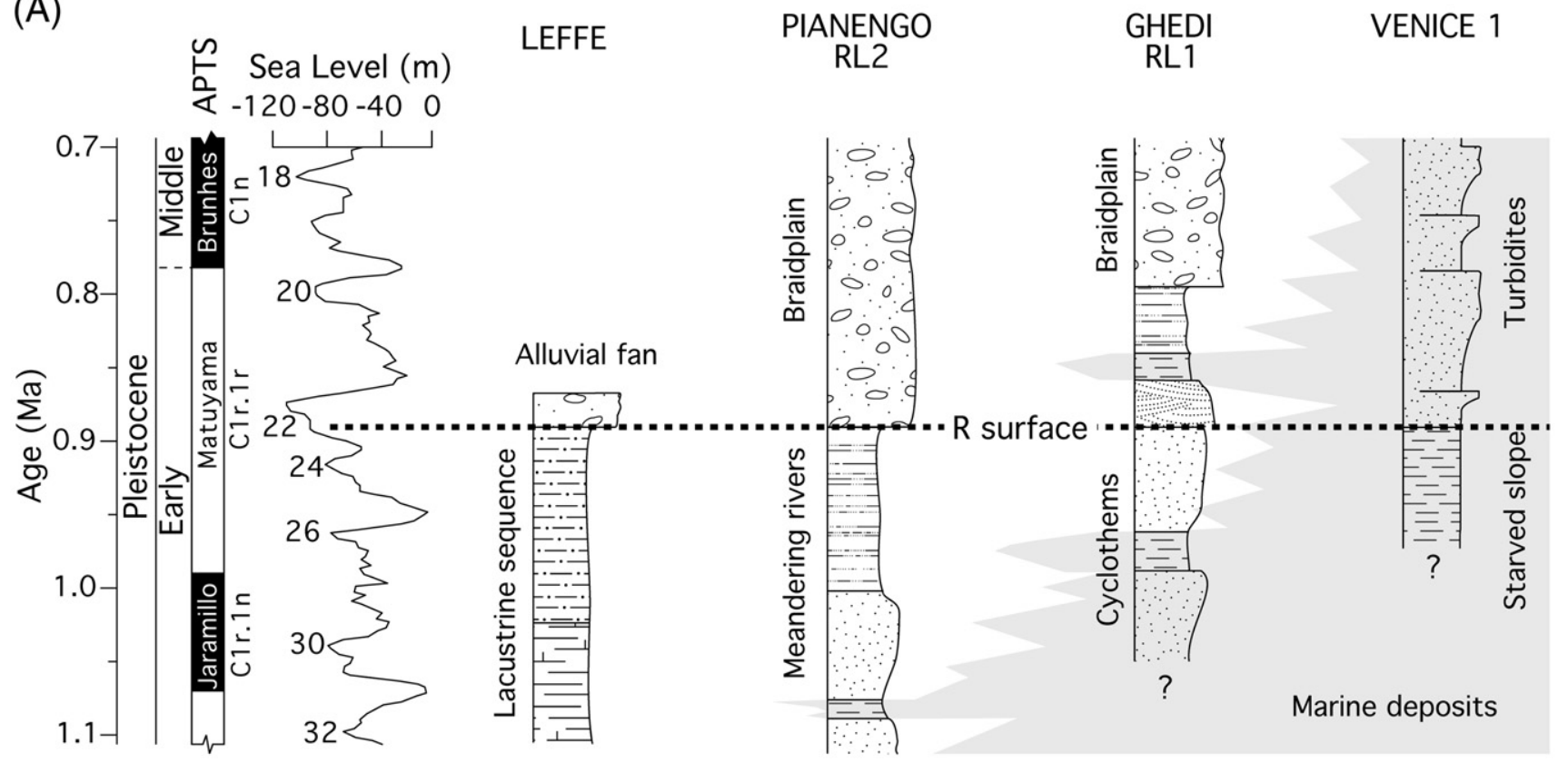

(B)

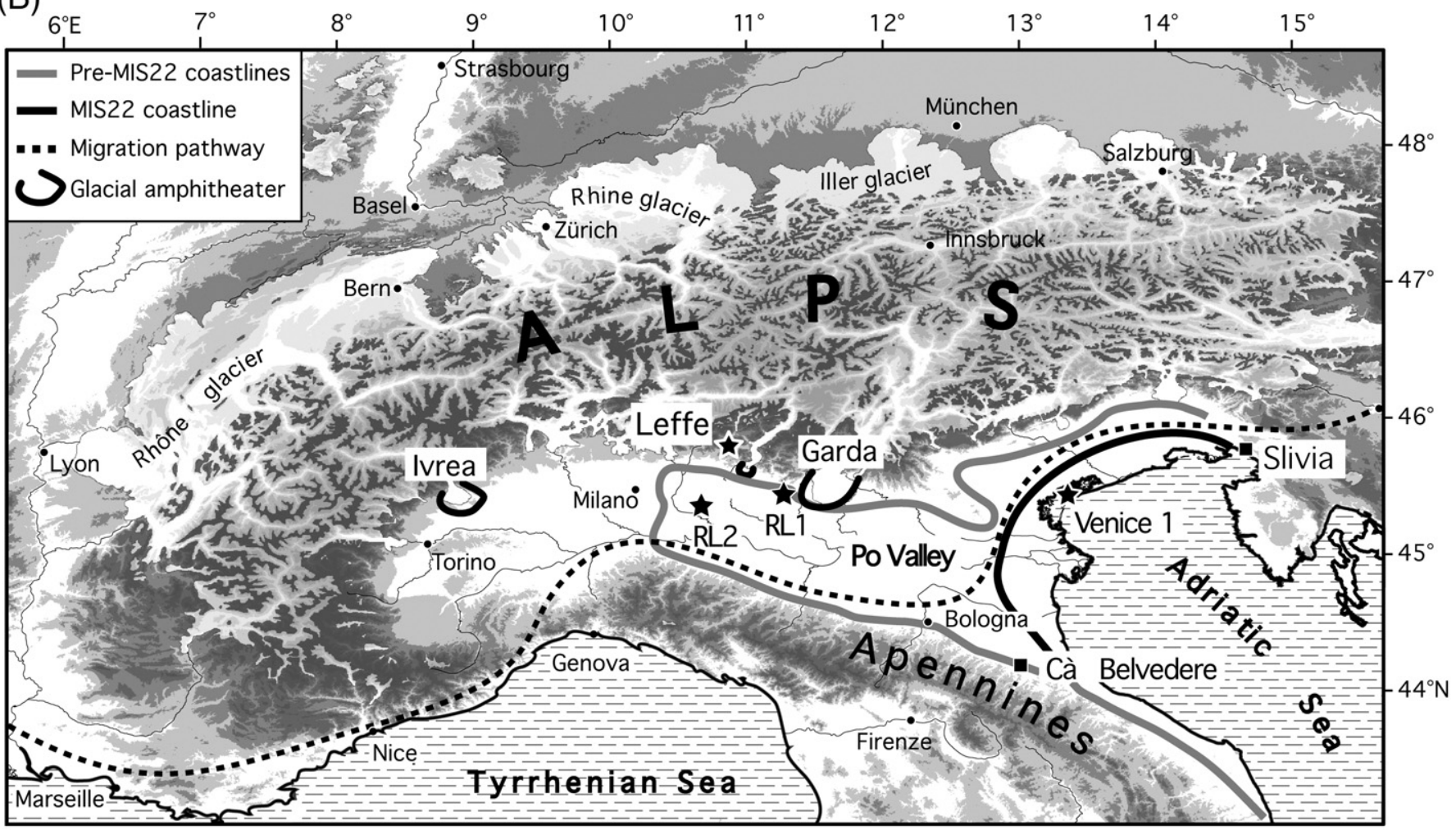

Fig. 5. Correlation of stratigraphic data (A) from the Southern Alps-Po Plain area (B) around MIS 22 ( 0.87 Ma) within subchron C1r.1r (0.99-0.78 Ma). (A) At MIS 22 time, the intensification of glacial activity in the Alps triggered the onset of high-energy sedimentation in different orographic and geodynamic settings of the Southern Alps-Po Valley system, e.g., Leffe (Muttoni et al., 2007), Pianengo (Muttoni et al., 2003), Ghedi (Scardia et al., 2006), and Venice (Kent et al., 2002) [time scale of Lourens et al. (2004)]. (B) As a consequence of high-energy fluvial progradation and eustatic lowstand at MIS 22 time, large stretches of the Po Valley became exposed for the first time, thus potentially opening new migration pathways (black line = MIS 22 coastline; dark gray line = nominal pre-MIS 22 coastline; black dashed line = potential migration pathway). The extension of the Alpine valley glaciers during the Last Glacial Maximum is from Ehlers and Gibbard (2004).

\section{Summary and conclusions}

A critical assessment of magnetostratigraphic and/or radiometric age constraints from key early hominin sites from Italy, France and Spain suggests that the main earliest peopling of southern Europe occurred sometime during the Matuyama Chron, before the Brunhes-
Matuyama boundary at $0.78 \mathrm{Ma}$ but after the Olduvai-Matuyama boundary at $1.77 \mathrm{Ma}$. More specifically, the best-dated oldest sites show temporal ranges overlapping within Chron C1r.1r, between the Jaramillo subchron and the Brunhes-Matuyama boundary (0.99$0.78 \mathrm{Ma}$ ), whereas the reminder of the oldest sites do not contradict this time window. 
Our preferred timing of the earliest peopling of Europe (0.99$0.78 \mathrm{Ma}$ ) may be related to the response of African and southern European climate to the inception of major northern hemisphere glacial oscillations corresponding to MIS 22 during the late Early Pleistocene. The onset of enhanced aridity in the Sahara at $\sim 0.95 \mathrm{Ma}$ with a burst at $0.87 \mathrm{Ma}$ (MIS 22) and the broadly coeval late Early Pleistocene development of extended loess steppes across the Eastern European Plain during the first major advances of the northern European and Alpine icecaps may have set in motion herds of large herbivores, notably E. antiquus from Africa and $M$. trogontherii from Asia, towards southern European refugia, and may have consequently motivated the immigration of hominins along with or after them. This follow-the-herd hypothesis, similar to hypotheses put forward by other authors (e.g., Turner, 1999; Arribas and Palmqvist, 1999), but more time-focused within the Pleistocene global climate record, is consistent with the suggestion by Palombo and Mussi (2006) that hominins first inhabited Italy in close temporal contiguity with the renovated middle Galerian faunas characterized by increasing numbers of middle-sized herbivores (and fewer predators).

We attempted to trace potential migration routes from a presumed East African homeland to southern Europe. The most likely route with large herbivores in mind is through the Nile Valley to the southern Mediterranean shores and across the Sinai corridor into the Levant. From the Levant the hominin-large herbivore migration would have proceeded into the Eastern European loess lowlands either across central Turkey-Bosphorous or across the Euphrates conduit, then from Eastern Europe into the Po Valley of northern Italy, which became largely exposed above sea-level for the first time in the Pleistocene at the MIS 22 low-stand; large herbivores and hominins may thence have migrated westward into southern France and Spain.

Three critical hominin sites apparently violate our age model (and possible related causes) of first main hominin immigration to southern Europe during C1r.1r. These are Fuentenueva-3 and Barranco León in southern Spain (Scott et al., 2007) and Pirro Nord in southern Italy (Arzarello et al., 2007), all of which yielded only Mode I lithic tools and have been attributed to the Matuyama before the Jaramillo. Further studies are required at Fuentenueva-3 and Barranco León in order to find the Jaramillo subchron and determine its position with respect to the archeologic levels in a continuous stratigraphic section or core, whereas at Pirro Nord, the current biostratigraphic age attribution of the sparse lithic tools needs to be tested with direct radiometric or magnetostratigraphic age constraints.

The climate-driven herd migration hypothesis predicts that sites containing proof of hominin presence in southern Europe should be associated with middle Galerian immigrant taxa from Africa and Asia. This does not necessarily mean, however, that sites containing proof of hominin presence associated with late Villafranchian taxa should be considered ipso facto older than Galerian sites. In fact, the middle Galerian faunal renovation could have taken place diachronously throughout physiographically complex southern Europe (e.g., Italy; Palombo et al., 2003), such that latest Villafranchian faunal relicts (Pirro Nord?) overlapped in time, and hence coexisted in space, with middle Galerian populations. Mammal associations could become quite interesting if independently dated rather than relied upon as accurate dating tools for regional or continental correlations across this critical time interval.

\section{Note added in proof}

Just published paleomagnetic and paleobotany data from the toolbearing site of Happisburgh-3 (UK) indicate hominin presence before the Brunhes-Matuyama boundary during either MIS $21(\sim 0.84 \mathrm{Ma})$ or MIS 25 ( $0.95 \mathrm{Ma}$ ) (Parfitt et al., 2010). The younger age attribution is compatible with our model whereby first colonization of Europe occurs at MIS $22(\sim 0.87 \mathrm{Ma})$ and subsequent spread including to higher latitudes during the prominent warm stage of MIS 21 or later.

\section{Acknowledgements}

Helpful comments by two anonymous reviewers allowed us to greatly improve the manuscript. GM and GS thank A.G. Segre, E. Segre Naldini, F. Parenti, G. Manzi, I. Biddittu, M.B. Cita, and M. Cremaschi for stimulating discussions on the Ceprano and Fontana Ranuccio sites; DVK benefited from co-teaching a graduate seminar with C. Swisher at Rutgers in Spring 2006 on Quaternary geochronology and paleomagnetism, and from many discussions with George Kukla on Pleistocene stratigraphy of Europe. Juan Cruz Larrasoaña provided a digital listing of the Sahara dust proxy record. This is Lamont-Doherty contribution \#7373.

\section{References}

Abbate, E., Woldehaimanot, B., Bruni, P., Falorni, P., Papini, M., Sagri, M., Girmay, S. Tecle, T.M., 2004. Geology of the Homo-bearing Pleistocene Dandiero Basin (Buia region, Eritrean Danakil depression). Rivista Italiana di Paleontologia e Stratigrafia 110, 5-34.

Agustí, J., Oms, O., Parés, J.M., 1999. Calibration of the Early-Middle Pleistocene transition in the continental beds of the Guadix-Baza Basin (SE Spain). Quaternary Science Review 18, 1409-1417.

Albianelli, A., Napoleone, G., 2004. Magnetostratigraphy of thw Homo-Bearing Pleistocene Dandiero Basin (Danakil depression, Eritrea). Rivista Italiana di Paleontologia e Stratigrafia 110, 35-44.

Ambrosetti, P. Azzaroli, A., Bonadonna, F.P. Follieri, M., 1972. A scheme of Pleistocene chronology for the Tyrrhenian side of central Italy. Bollettino della Società Geologica Italiana 91, 169-184.

Antón, S.C., Swisher III, C.C., 2004. Early dispersals of Homo from Africa. Annual Review of Anthropology 33, 271-296.

Antoniazzi, A., Cremaschi, M., Gagnepain, J., Peretto, C., 1992. Indagini preliminari sulla stratigrafia del giacimento di Cà Belvedere di Monte Poggiolo: aspetti sedimentologici e pedologici. In: Peretto, C. (Ed.), I primi abitanti della valle Padana: Monte Poggiolo nel quadro delle conoscenze europee. Jaca Book, Milan, pp. 255-273.

Aouadi, N., 2001. New Data on the Diversity of Elephants (Mammalia, Proboscidea) in the Early and Early Middle Pleistocene of France. In: Cavarretta, G., Gioia, P., Mussi, M., Palombo, M.R. (Eds.), The World of Elephants. Proceedings of the First International Congress. Consiglio Nazionale delle Ricerche, Rome, pp. 81-84.

Arribas, A., Palmqvist, P., 1999. On the ecological connection between sabre-tooths and hominids: faunal dispersal events in the lower pleistocene and a review of the evidence for the first human arrival in Europe. Journal of Archaeological Science 26, 571-585.

Arzarello, M., Marcolini, F., Pavia, G., Pavia, M., Petronio, C., Petrucci, M., Rook, L., Sardella, R., 2007. Evidence of earliest human occurrence in Europe: the site of Pirro Nord (Southern Italy). Naturwissenschaften 94, 107-112.

Asfaw, B., Beyene, Y., Suwa, G., Walker, R.C., White, T.D., WoldeGabriel, G., Yemane, T. 1992. The earliest Acheulean from Konso-Gardula. Nature 360, 732-735.

Ascenzi, A., Biddittu, I., Cassoli, P.F., Segre, A.G., Segre Naldini, E., 1996. A calvarium of late Homo erectus from Ceprano, Italy. Journal of Human Evolution 31, 409-423.

Ascenzi, A., Mallegni, F., Manzi, G., Segre, A.G., Segre Naldini, E., 2000. A re-appraisal of Ceprano calvaria affinities with Homo erectus, after the new reconstruction. Journal of Human Evolution 39, 443-450.

Azzaroli, A., 1983. Quaternary mammals and the "End-Villafranchian" dispersal eventa turning point in the history of Eurasia. Palaeogeography Palaeoclimatology Palaeoecology 44, 117-139.

Bahain, J.-J., Falguères, C., Voinchet, P., Duval, M., Dolo, J.-M., Despriée, J., Garcia, T., Tissoux, H., 2007. Electron spin resonance (ESR) dating of some European late lower Pleistocene sites. Quaternaire 18 (2), 175-186.

Bennett, K.D., Tzedakis, P.C., Willis, K.J., 1991. Quaternary refugia of north European trees. Journal of Biogeography 18, 103-115.

Berger, W.H., Bickert, T., Schmidt, H., Wefer, G., 1993. 22. Quaternary oxygen isotope record of pelagic foraminifers: Site 806, Ontong Java Plateau. Proceedings ODP: Scientific Results, vol. 130, pp. 381-395.

Berger, G.W., Perez-Gonzalez, A., Carbonell, E., Arsuaga, J.L., Bermudez de Castro, J.-M., Ku, T.-L., 2008. Luminescence chronology of cave sediments at the Atapuerca paleoanthropological site, Spain. Journal of Human Evolution 55, 300-311.

Berggren, W.A., Hilgen, F.J., Langereis, C.G., Kent, D.V., Obradovich, J.D., Raffi, I., Raymo, M.E., Shackleton, N.J., 1995. Late Neogene chronology: new perspectives in highresolution stratigraphy. Geological Society of America Bulletin 107, 1272-1287.

Bernal, M.T., Moncel, M.-H., 2004. Contribution to the study of the technology of Paleolithic archaic of the south of Europe according to the Analytical Logical System (SLA). Application to the sites of Vallonnet (Roquebrune-Cape-Martin, France), Gran Dolina TD6 (Burgos, Spain), Cà Belvedere of Monte Poggiolo (Forli, Italy) and Barranco León and Fuente Nueva 3 (Orce, Spain). L'Anthropologie 108 307-329.

Bertini, A., 2000. Pollen record from Colle Curti and Cesi: Early and Middle Pleistocene mammal sites in the Umbro-Marchean Apennine Mountains (central Italy). Journal of Quaternary Science 15 (8), 825-840.

Biddittu, I., Cassoli, P.F., Radicati Di Brozolo, F., Segre, A.G., Segre Naldini, E., Villa, I., 1979. Anagni, a K-Ar dated Lower and Middle Pleistocene Site, Central Italy: preliminary Report. Quaternaria 21, 53-71.

Biddittu, I., Celletti, P., 2001. Plio-Pleistocene Proboscidea and Lower Palaeolithic bone industry of southern Latium (Italy). In: Cavarretta, G., Gioia, P., Mussi, M., Palombo, 
M.R. (Eds.), The World of Elephants. Proceedings of the First International Congress. Consiglio Nazionale delle Ricerche, Rome, pp. 91-96.

Bisi, F., Fontana, L., Proli, F., Peretto, C., 1992. L'industria di Cà Belvedere di Monte Poggiolo. In: Peretto, C. (Ed.), I primi abitanti della valle Padana: Monte Poggiolo nel quadro delle conoscenze europee. Jaca Book, Milan, pp. 348-357.

Breda, M., Marchetti, M., 2005. Systematical and biochronological review of PlioPleistocene Alceini (Cervidae; Mammalia) from Eurasia. Quaternary Science Reviews $24,775-805$.

Bruner, E., Manzi, G., 2007. Landmark-based shape analysis of the archaic Homo calvarium from Ceprano (Italy). American Journal of Physical Anthropology 132, $355-366$.

Carbonell, E., Bermudez de Castro, J.M., Arsuaga, J.L., Diez, J.C., Rosas, A., Cuenca-Bescos, G., Sala, R., Mosquera, M., Rodriguez, X.P., 1995. Lower Pleistocene hominids and artifacts from Atapuerca-TD6 (Spain). Science 269, 826-829.

Carbonell, E., Bermúdez de Castro, J.M., Parés, J.M., Pérez-González, A., Cuenca-Bescós, G., Ollé, A., Mosquera, M., Huguet, R., van der Made, J., Rosas, A., Sala, R., Vallverdú, J., García, N., Granger, D.E., Martinón-Torres, M., Rodríguez, X.P., Stock, G.M., Vergès J.M., Allué, E., Burjachs, F., Cáceres, I., Canals, A., Benito, A., Díez, C., Lozano, M., Mateos, A., Navazo, M., Rodríguez, J., Rosell, J., Arsuaga, J.L., 2008. The first hominin of Europe. Nature 452, 465-470.

Cande, S.C., Kent, D.V., 1995. Revised calibration of the geomagnetic polarity timescale for the Late Cretaceous and Cenozoic. Journal of Geophysical Research 100 (B4), 6093-6095.

Carraro, F., Lanza, R., Perotto, A., Zanella, E., 1991. L'evoluzione morfologica del Biellese occidentale durante il Pleistocene inferiore e medio, in relazione all'inizio della costruzione dell'Anfiteatro Morenico d'Ivrea. Bollettino del Museo Regionale di Scienze Naturali di Torino 9 (1), 99-117.

Carrion, J.S., Yll, E.I., Walker, M.J., Legaz, A.J., Chain, C., Lopez, A., 2003. Glacial refugia of temperate, Mediterranean and Ibero-North African flora in south-eastern Spain: new evidence from cave pollen at two Neanderthal man sites. Global Ecology \& Biogeography 12, 119-129.

Celletti, P., Giovinazzo, C., Molinaro, A., Biddittu, I., Zarattini, A., 2001. A Middle Pleistocene deposit with Elephas antiquus remains near Colleferro (Roma). In: Cavarretta, G., Gioia, P., Mussi, M., Palombo, M.R. (Eds.), The World of Elephants. Proceedings of the First International Congress. Consiglio Nazionale delle Ricerche, Rome, pp. 34-37.

Champagnac, J.-D., Molnar, P., Anderson, R., Sue, C., Delacou, B., 2007. Quaternary erosion-induced isostatic rebound in the western Alps. Geology 35 (3), 195-198.

Champagnac, J.-D., Schlunegger, F., Norton, K., von Blanckenburg, F., Abbühl, L.M Schwab, M., 2009. Erosion-driven uplift of the modern Central Alps. Tectonophysics 474 (1-2), 236-249.

Clement, B.M., 2004. Dependence of the duration of geomagnetic polarity reversals on site latitude. Nature 428, 637-640.

Coltorti, M., Cremaschi, M., Delitala, M.C., Esu, D., Fornaseri, M., McPherron, A., Nicoletti, M., van Otterloo, R., Peretto, C., Sala, B., Schmidt, V., Sevink, J., 1982. Reversed magneti polarity at an early Lower Palaeolithic site in Central Italy. Nature 300,173-176.

Coltorti, M., Albianelli, A., Bertini, A., Ficcarelli, G., Laurenzi, M.A., Napoleone, G., Torre, D., 1998. The Colle Curti mammal site in the Colfiorito area (Umbria-Marchean Apennine, Italy): geomorphology, paleomagnetism and palinology. Quaternary International 47 (48), 107-116.

Coltorti, M., Feraud, G., Marzoli, A., Peretto, C., Ton-Thate, T., Voinchet, P., Bahain, J.-J. Minelli, A., Thun Hohenstein, U., 2005. New ${ }^{40} \mathrm{Ar} /{ }^{39} \mathrm{Ar}$, stratigraphic and palaeoclimatic data on the Isernia La Pineta Lower Palaeolithic site, Molise, Italy. Quaternary International 131, 11-22.

Cremaschi, M., 1987. Paleosols and Vetusols in the Central Po Plain (Northern Italy). A study in Quaternary Geology and Soil Development. Unicopli, Milano, 306 pp.

De Lumley, H., 1988. La stratigraphie du remplissage de la grotte du Vallonnet. L'Anthropologie 92, 407-428.

Demir, T., Westaway, R., Bridgland, D., Seyrek, A., 2007. Terrace staircases of the River Euphrates in southeast Turkey, northern Syria and western Iraq: evidence for regional surface uplift. Quaternary Science Reviews 26, 2844-2863.

Dennell, R.W., Roebroeks, W., 1996. The earliest colonization of Europe: the short chronology revisited. Antiquity 70, 535-542.

Dennell, R.W., 2008. Human migration and occupation of Eurasia. Episodes 31, 207-210.

Derricourt, R., 2005. Getting "out of Africa": sea crossings, land crossings and culture in the hominin migrations. Journal of World Prehistory 19, 119-132.

Despriée, J., Gageonnet, R., 2003. La très haute nappe alluviale d'âge pléistocène inférieur de la vallée de la Creuse à Eguzon (Indre): figures de cryoturbations, habitats préhistoriques et datations absolues. Bulletin de la Société Géologique de France 174, 383-400.

Despriée, J., Gageonnet, R., Voinchet, P., Bahain, J.-J., Falguères, C., Varache, F., Courcimault, G., Dolo, J.-M., 2006. Une occupation humaine au Pléistocène inférieu sur la bordure nord du Massif central. Comptes Rendus Palevol 5, 821-828.

Dodonov, A.E., Zhou, L.P., Markova, A.K., Tchepalyga, A.L., Trubikhin, V.M., Aleksandrovski, A.L. Simakova, A.N., 2006. Middle-Upper Pleistocene bio-climatic and magnetic records of the Northern Black Sea Coastal Area. Quaternary International 149, 44-54.

Echassoux, A., 2004. Taphonomy, palaeoecology and zooarchaeology of the lowe Pleistocene mammals of Vallonnet cave (Roquebrune-Cap-Martin, Alpes-Maritimes, France). L'Anthropologie 108, 11-53.

Ehlers, J., Gibbard, P.L. (Eds.), 2004. Quaternary Glaciations-Extent and Chronology, Part I: Europe. : Developments in Quaternary Science, vol. 2. Elsevier, Amsterdam.

Fairbanks, R.G., 1989. A 17, 000-year glacio-eustatic sea level record: influence of glacial melting rates on the Younger Dryas event and deep-ocean circulation. Nature 342, 637-642.

Faustov, S.S., Virina, E.I., Tsatskin, A.I., Gendler, T.S., Heller, F., 2009. The Matuyama/ Brunhes boundary in loess sections in the south of the East European Plain and their correlation on the basis of palaeomagnetic and palaeopedologic data. Quaternary International 201,60-66.

Florindo, F., Marra, F., 1995. A revision of the stratigraphy for the middle Pleistocene continental deposits of Rome (Central Italy): paleomagnetic data. Annals of Geophysics 38, 177-188.

Gabunia, L., Vekua, A., Lordkipanidze, D., Swisher, C.C., Ferring, R., Justus, A., Nioradze, M., Tvalchrelidze, M., Anton, S.C., Bosinski, G., Joris, O., de Lumley, M.-A., Majsuradze, G., Mouskhelishvili, A., 2000. Earliest Pleistocene hominid cranial remains from Dmanisi, Republic of Georgia: Taxonomy, geological setting, and age. Science 288, 1019-1025.

Gagnepain, J., 1996. Etude magnetostratigraphique de sites du Pleistocene inferieur et moyen des Alpes-Maritimes et d'Italie: Grotte du Vallonnet, Marina Airport, Ca' Belvedere di Monte Poggiolo, Isernia La Pineta, Venosa Loreto. Museum national d'Histoire naturelle, Paris. 333 pp.

Gagnepain, J., Hedley, I., Bahain, J.-J., Wagner, J.J., 1992. Etude magnetostratigraphique du site de Ca' Belvedere di Monte Poggiolo (Forli, Italie) et de son contexte stratigraphique. Premiers resultats. In: Peretto, C. (Ed.), I primi abitanti della valle Padana: Monte Poggiolo nel quadro delle conoscenze europee. Milan, Jaca Book, pp. 319-329.

Geraads, D., Raynal, J.-P., Eisenmann, V., 2004. The earliest human occupation of North Africa: a reply to Sahnouni et al. (2002). Journal of Human Evolution 46, 751-761.

Gibert, L., Scott, G., Martin, R., Gibert, J., 2007. The Early to Middle Pleistocene boundary in the Baza Basin (Spain). Quaternary Science Reviews 26, 2067-2089.

Giraudi, C., Mottura, A., Sala, B., Siori, M.S., Bormioli, D., 2003. The Castagnone site (Cerrina Valley, Monferrato hills, NW Italy): Early Pleistocene sedimentary record and biochronology. Rivista Italiana di Paleontologia e Stratigrafia 109, 517-526.

Gliozzi, E., Abbazzi, L., Argenti, P., Azzaroli, A., Caloi, L., Capasso Barbato, L., Di Stefano, G., Esu, D., Ficcarelli, G., Girotto, O., Kotsakis, T., Masini, F., Mazza, P., Mezzabotta, C., Palombo, M.R., Petronio, C., Rook, L., Sala, B., Sardella, R., Zanalda, E., Torre, D., 1997. Biochronology of selected Mammals, Molluscs and Ostracods from the Middle Pliocene to the Late Pleistocene in Italy. The state of the art. Rivista Italiana di Paleontologia e Stratigrafia 103 (3), 369-388.

Goren-Inbar, N., Feibel, C.S., Verosub, K.L., Melamed, Y., Kislev, M.E., Tchernov, E., Saragusti, I., 2000. Pleistocene Milestones on the Out-of-Africa Corridor at Gesher Benot Ya'aqov, Israel. Science 289, 944-947.

Gracia, F.J., Rodriguez-Vidal, J., Caceres, L.M., Belluomini, G., Benavente, J., Alonso, C., 2008. Diapiric uplift of an MIS 3 marine deposit in SW Spain: Implications for Late Pleistocene sea level reconstruction and palaeogeography of the Strait of Gibraltar. Quaternary Science Reviews 27, 2219-2231.

Haase, D., Fink, J., Haase, G., Ruske, R., Pecsi, M., Richter, H., Altermann, M., Jager, K.-D., 2007. Loess in Europe-its spatial distribution based on a European Loess Map, scale 1:2, 500, 000. Quaternary Science Reviews 26, 1301-1312.

Haynes, V., 1973. The Calico site: artifacts or geofacts? Science 181, 305-310.

Head, M.J., Gibbard, P.L., 2005. Early-Middle Pleistocene transitions: an overview and recommendation for the defining boundary. In: Head, M.J., Gibbard, P.L. (Eds.), Early-Middle Pleistocene Transitions: The Land-Ocean Evidence: Special Publications, vol. 247. Geological Society, London, pp. 1-18.

Kent, D.V., Opdyke, N.D., Ewing, M., 1971. Climate change in the North Pacific using icerafted detritus as a climatic indicator. Geological Society of America Bulletin 82, 2741-2754.

Kent, D.V., Rio, D., Massari, F., Kukla, G., Lanci, L., 2002. Emergence of Venice during the Pleistocene. Quaternary Science Reviews 21, 1719-1727.

Kostopoulos, D.S., Palombo, M.R., Alberdi, M.-T., Valli, A.M.F., 2007. Pliocene to Pleistocene large mammal diversity and turnover in North Mediterranean region: the Greek Peninsula with respect to the Iberian and Italian ones. Geodiversitas 29 (3), 401-419.

Kotsakis, T., Esu, D., Girotti, O., 1992. A post-Villafranchian cold event in Central Italy testified by continental molluscs and rodents. Bollettino della Società Geologica Italiana 111, 335-340.

Kuhn, S.L., 2002. Paleolithic Archeology in Turkey. Evolutionary Anthropology 11, $198-210$

Kukla, G., Cilek, V., 1996. Plio-Pleistocene megacycles: record of climate and tectonics. Palaeogeography, Palaeoclimatology, Palaeoecology 120, 171-194.

Larrasoaña, J.C., Roberts, A.P., Rohling, E.J., Winklhofer, M., Wehausen, R., 2003. Three million years of monsoon variability over the northern Sahara. Climate Dynamics 21, 689-698.

Langereis, C.G., Dekkers, M.J., de Lange, G.J., Paterne, M., van Santvoort, P.J.M., 1997. Magnetostratigraphy and astronomical calibration of the last $1.1 \mathrm{Myr}$ from an eastern Mediterranean piston core and dating of short events in the Brunhes. Geophysical Journal International 129, 75-94.

Langereis, C.G., Krijgsman, W., Muttoni, G., Menning, M., 2010. Magnetostratigraphyconcepts, definitions, and applications. Newsletter on Stratigraphy 43 (3), 207-233.

Lee, J.R., Rose, J., Candy, I., Barendregt, R.W., 2006. Sea-level changes, river activity, soil development and glaciation around the western margins of the southern North Sea Basin during the Early and early Middle Pleistocene: evidence from Pakefield, Suffolk, UK. Journal of Quaternary Science 21 (2), 155-179.

Lisiecki, L.E., Raymo, M.E., 2005. A Pliocene-Pleistocene stack of 57 globally distributed benthic $\delta^{18}$ O records. Paleoceanography 20, PA1003. doi:10.1029/2004PA001071.

Lister, A.M., Sher, A.V., van Essen, H., Wei, G, 2005. The pattern and process of mammoth evolution in Eurasia. Quaternary International 126-128, 49-64.

Lo Bello, P., Féraud, G., Hall, C.M., York, D., Lavina, P., Bernat, M., 1987. ${ }^{40} \mathrm{Ar} /{ }^{39} \mathrm{Ar}$ stepheating and laser fusion dating of a quaternary pumice from Neschers, Massif Central, France: the defeat of xenocrystic contamination. Chemical Geology: Isotope Geoscience section 66, 61-71. 
The Neogene Period. In: Lourens, L., Hilgen, F., Shackleton, N.J., Laskar, J., Wilson, D. (Eds.), Geologic Time Scale. Cambridge University Press, Cambridge.

Ludwig, K.R., Renne, P.R., 2000. Geochronology on the Paleoanthropological time scale. Evolutionary Anthropology 9, 101-110.

Lycett, S.J., von Cramon-Taubadel, N., 2008. Acheulean variability and hominin dispersals: a model-bound approach. Journal of Archaeological Science 35 (3), 553-562.

Manzi, G., 2004. Human evolution at the Matuyama-Brunhes boundary. Evolutionary Anthropology 13, 11-24.

Marra, A.C., 2005. Pleistocene mammals of Mediterranean islands. Quaternary International 129, 5-14.

Marra, F., Florindo, F., Karner, D.B., 1998. Paleomagnetism and geochronology of early Middle Pleistocene depositional sequences near Rome: comparison with the deepsea $\delta^{18} \mathrm{O}$ record. Earth and Planetary Science Letters 159, 147-164.

Martinez-Navarro, B., Palombo, M.R., 2004. Occurrence of the Indian genus Hemibos (Bovini, Bovidae, Mammalia) at the Early-Middle Pleistocene transition in Italy. Quaternary Research 61, 314-317.

Martinez-Navarro, B., Rook, L., Segid, A., Yosief, D., Ferreti, M.P., Shoshani, J., Tecle, T.M., Libsekal, Y., 2004. The large fossil mammals from Buia (Eritrea): systematics, biochronology and paleoenvironments. Rivista Italiana di Paleontologia e Stratigrafia 110, 61-88.

Martinez-Navarro, B., Belmaker, M., Bar-Yosef, O., 2009. The large carnivores from 'Ubeidiya (early Pleistocene, Israel): biochronological and biogeographical implications. Journal of Human Evolution 56, 514-524.

Masini, F., Sala, B., 2007. Large- and small-mammal distribution patterns and chronostratigraphic boundaries from the Late Pliocene to the Middle Pleistocene of the Italian peninsula. Quaternary International 160, 43-56.

Massari, F., Rio, D., Serandrei Barbero, R., Asioli, A., Capraro, L., Fornaciari, E., Vergerio, P.P., 2004. The environment of Venice area in the past two million years. Palaeogeography Palaeoclimatology Palaeoecology 202, 273-308.

Médail, F., Diadema, K., 2009. Glacial refugia influence plant diversity patterns in the Mediterranean Basin. Journal of Biogeography 36, 1333-1345.

Milli, S., Palombo, M.R., Petronio, C., Sardella, R., 2004. The Middle Pleistocene deposits of the Roman Basin (Latium, Italy): an integrated approach of mammal biochronology and sequence stratigraphy. Rivista Italiana di Paleontologia e Stratigrafia 110 (2), 559-569.

Moullé, P.E., Lacombat, F., Echassoux, A., 2006. Contribution of the large mammals of Vallonnet cave (Roquebrune-Cap-Martin, Alpes-Maritimes, France) to the knowledge of biochronological frame of the second half of the Lower Pleistocene in Europe. L'Anthropologie 110, 837-849.

Muttoni, G., Carcano, C., Garzanti, E., Ghielmi, M., Piccin, A., Pini, R., Rogledi, S., Sciunnach, D., 2003. Onset of major pleistocene glaciations in the Alps. Geology 31, 989-992.

Muttoni, G., Ravazzi, C., Breda, M., Laj, C., Kissel, C., Mazaud, A., Pini, R., Garzanti, E., 2007. Magnetostratigraphy of the Leffe lacustrine succession (Southern Alps, Italy): evidence for an intensification of glacial activity in the Alps at Marine Isotope Stage 22 (0.87 Ma). Quaternary Research 67, 161-173.

Muttoni, G., Scardia, G., Kent, D.V., Swisher, C.C., Manzi, G., 2009. Pleistocene magnetochronology of early hominin sites at Ceprano and Fontana Ranuccio, Italy. Earth and Planetary Science Letters 286, 255-268.

Napoleone, G., Albianelli, A., Azzaroli, A., Mazzini, M., 2001. The Poggio Rosso locality calibrated to the end-Pliocene and its significance for dating the Late Villafranchian mammal faunas of the Upper Valdarno (Central Italy). Rivista Italiana di Paleontologia e Stratigrafia 107, 287-296.

Napoleone, G., Albianelli, A., Azzaroli, A., Bertini, A., Magi, M., Mazzini, M., 2003. Calibration of the Upper Valdarno Basin to the Plio-Pleistocene for correlating the Apennine continental sequences. Il Quaternario 16, 131-166.

Oms, O., Parés, J.M., Martínez-Navarro, B., Agustí, J., Toro, I., Martínez-Fernández, G. Turq, A., 2000. Early human occupation of Western Europe: paleomagnetic dates for two paleolithic sites in Spain. Proceedings of the National Academy of Sciences 97, 10666-10670.

Opdyke, N., Lindsay, E., Kukla, G., 1983. Evidence for earlier date of Ubeidiya, Israel hominid site. Nature 304, 375.

O’Regan, H.J., 2008. The Iberian Peninsula - corridor or cul-de-sac? Mammalian faunal change and possible routes of dispersal in the last 2 million years. Quaternary Science Reviews 27, 2136-2144.

O'Regan, H.J., Bishop, L.C., Lamb, A., Elton, S., Turner, A., 2005. Large mammal turnover in Africa and the Levant between 1.0 and $0.5 \mathrm{Ma}$. In: Head, M.J., Gibbard, P.L. (Eds.), Early-Middle PleistoceneTransitions: The Land-Ocean Evidence. Special Publications, vol. 247. Geological Society, London, pp. 231-249.

Palombo, M.R., Ferretti, M.P., 2005. Elephant fossil record from Italy: knowledge, problems, and perspectives. Quaternary International 126-128, 107-136.

Palombo, M.R., Mussi, M., 2006. Large mammal guilds at the time of the first human colonization of Europe: the case of the Italian Pleistocene record. Quaternary International 149, 94-103.

Palombo, M.R., Sardella, R., 2007. Biochronology and biochron boundaries: a real dilemma or a false problem? An example based on the Pleistocene large mammalian faunas from Italy. Quaternary International 160, 30-42.

Palombo, M.R., Azanza, B., Alberdi, M.T., 2003. Italian mammal biochronology from the Latest Miocene to the Middle Pleistocene: a multivariate approach. Geologica Romana 36, 335-368.

Parés, J.M., Pérez-Gonzalez, A., 1995. Paleomagnetic age for homind fossils at Atapuerca Archaeological site, Spain. Science 269, 830-832.

Parés, J.M., Pérez-Gonzalez, A., 1999. Magnetochronology and stratigraphy at Gran Dolina section, Atapuerca (Burgos, Spain). Journal of Human Evolution 37, 325-342.
Parés, J.M., Pérez-Gonzalez, A., Rosas, A., Benito, A., Bermudez de Castro, J.M., Carbonell, E., Huguet, R., 2006. Matuyama-age lithic tools from the Sima del Elefante site, Atapuerca (northern Spain). Journal of Human Evolution 50, 163-169.

Parfitt, S.A., Barendregt, R.W., Breda, M., Candy, I., Collins, M.J., Coope, G.R., Durbidge, P., Field, M.H., Lee, J.R., Lister, A.M., Mutch, R., Penkman, K.E.H., Preece, R.C., Rose, J., Stringer, C.B., Symmons, R., Whittaker, J.E., Wymer, J.J., Stuart, A.J., 2005. The earliest record of human activity in northern Europe. Nature 438, 1008-1012.

Parfitt, S.A., Ashton, N.M., Lewis, S.G., Abel, R.L., Coope, G.R., Field, M.H., Gale, R., Hoare, P.G., Larkin, N.R., Lewis, M.D., Karloukovski, V., Maher, B.A., Peglar, S.M., Preece, R.C. Whittaker, J.E., Stringer, C.B., 2010. Early Pleistocene human occupation at the edge of the boreal zone in northwest Europe. Nature 466, 229-233.

Peel, M.C., Finlayson, B.L., McMahon, T.A., 2007. Updated world map of the KoeppenGeiger climate classification. Hydrology and Earth System Sciences 11, 1633-1644.

Peretto, C., 2006. The first peopling of southern Europe: the Italian case. Comptes Rendus Palevol 5, 283-290.

Peretto, C., Amore, F.O., Antoniazzi, A., Antoniazzi, A., Bahain, J.-J., Cattani, L., Cavallini, E., Esposito, P., Falguères, C., Gagnepain, J., Hedley, I., Laurent, M., Lebreton, V., Longo, L., Milliken, S., Monegatti, P., Ollè, A., Pugliese, N., Renault-Miskovsky, J., Sozzi, M. Ungaro, S., Vannucci, S., Verges, J.-M., Wagner, J.-J., Yokoyama, Y., 1998. L'industrie lithique de Ca' Belvedere di Monte Poggiolo: stratigraphie, matiere premiere, typologie, remontages et traces d'utilisation. L'Anthropologie 102, 343-365.

Piperno, M., Tagliacozzo, A., 2001. The Elephant Butchery Area at the Middle Pleistocene site of Notarchirico (Venosa, Basilicata, Italy). In: Cavarretta, G. Gioia, P., Mussi, M., Palombo, M.R. (Eds.), The World of Elephants. Proceedings of the First International Congress. Consiglio Nazionale delle Ricerche, Rome, pp. 230-236

Quade, J., Levin, N., Semaw, S., Stout, D., Renne, P., Rogers, M.J., Simpson, S., 2004 Paleoenvironments of the earliest stone toolmakers, Gona, Ethiopia. Geological Society of America Bulletin 116, 1529-1544.

Raia, P., Piras, P., Kotsakis, T., 2006. Detection of Plio-Quaternary large mammal communities of Italy. An integration of fossil faunas biochronology and similarity. Quaternary Science Reviews 25, 846-854.

Raynal, J.-P., Magoga, L., Bindon, P., 1995. Tephrofacts and the first human occupation of the French Massif Central. In: Roebroeks, W., van Kolfschoten, T. (Eds.), The Eariest Occupation of Europe. University of Leiden, Leiden, pp. 129-146.

Raynal, J.-P., Vernet, G., Paquereau, M.-M., Papy, G., 2001. Sédiments, tephras et pollens dans le complexe de Solheilhac (Blanzac, Haute-Loire). Les dossiers de l'ArchéoLogis 1, 191-209.

Raynal, J.-P., Sihi Alaoui, F.-Z., Magoga, L., Mohib, A., Zouak, M., 2002. Casablanca and the earliest occupation of north Atlantic Morocco. Quaternaire 13 (1), 65-77.

Rink, W.J., Bartoll, J., Schwarcz, H.P., Shane, P., Bar-Yosef, O., 2007. Testing the reliability of ESR dating of optically exposed buried quartz sediments. Radiation Measurements 42, 1618-1626.

Roebroeks, W., van Kolfschoten, T., 1994. The earliest occupation of Europe: a shor chronology. Antiquity 68, 489-503.

Roebroeks, W., 2001. Hominid behaviour and the earliest occupation of Europe: an exploration. Journal of Human Evolution 41, 437-461.

Ron, H., Porat, N., Ronen, A., Tchernov, E., Horwitz, L.K., 2003. Magnetostratigraphy of the Evron Member-implications for the age of the Middle Acheulian site of Evron Quarry. Journal of Human Evolution 44, 633-639.

Ryan, W.B.F., Major, C.O., Lericolais, G., Goldstein, S.L., 2003. Catastrophic flooding in the Black Sea. Annual Review of Earth and Planetary Science 31, 525-554.

Sahnouni, M., Hadjouis, D., van der Made, J., Derradji, A.-e.-K., Canals, A., Medig, M., Belahrech, H., Rabhi, M., 2002. Further research at the Oldowan site of Ain Hanech, North-eastern Algeria. Journal of Human Evolution 43, 925-937.

Sahnouni, M., Hadjouis, D., van der Made, J., Derradji, A.-e.-K., Canals, A., Medig, M. Belahrech, H., Harichane, Z., Rabhi, M., 2004. On the earliest human occupation in North Africa: a response to Geraads et al. (2004). Journal of Human Evolution 46, 763-775.

Said, R., 1993. The River Nile; geology, hydrology and utilization. Pergamon, Oxford.

Sardella, R., Palombo, M.R., Petronio, C., Bedetti, C., Pavia, M., 2006. The early Middle Pleistocene large mammal faunas of Italy: an overview. Quaternary International 149, 104-109.

Scardia, G., Muttoni, G., Sciunnach, D., 2006. Subsurface magnetostratigraphy of Pleistocene sediments from the Po Plain (Italy): Constraints on rates of sedimentation and rock uplift. Geological Society of America Bulletin 118 (11/12), 1299-1312.

Scardia, G., Donegana, M., Muttoni, G., Ravazzi, C., Vezzoli, G., 2010. Late Matuyama climate forcing on sedimentation at the fringe of the Southern Alps (Italy) Quaternary Science Reviews 29, 832-846.

Scott, G.R., Gibert, L., Gibert, J., 2007. Magnetostratigraphy of the Orce region (Baza Basin), SE Spain: New chronologies for Early Pleistocene faunas and hominid occupation sites. Quaternary Science Reviews 26, 415-435.

Scott, G.R., Gibert, L., 2009. The oldest hand-axes in Europe. Nature 461, 82-85.

Ségalen, L., Lee-Thorp, J.A., Cerling, T., 2007. Timing of C4 grass expansion across subSaharan Africa. Journal of Human Evolution 53, 549-559.

Semaw, S., Renne, P., Harris, J.W.K., Feibel, C.S., Bernor, R.L., Fesseha, N., Mowbray, K. 1997. 2.5-million-year-old stone tools from Gona, Ethiopia. Nature 385, 333-336.

Shackleton, N.J., 1995. New data on the evolution of Pliocene climate variability. In: Vrba, E., Denton, G.H., Partridge, T.C., Burckle, L.H. (Eds.), Palaeoclimate and evolution, with emphasis on human origins. Yale University Press, New Haven, pp. 242-248.

Shackleton, N.J., Opdyke, N.D., 1976. Oxygen-isotope and paleomagnetic stratigraphy of Pacific core V28-239: Late Pliocene to latest Pleistocene. Geological Society of America Memoir 145, 449-464. 
Straus, L.G., 2001. Africa and Iberia in the Pleistocene. Quaternary International 75. 91-102.

Thouveny, N., Bonifay, E., 1984. New chronological data on European Plio-Pleistocene faunas and hominid occupation sites. Nature 308, 355-358.

Torre, D., Albianelli, A., Azzaroli, A., Ficcarelli, G., Magi, M., Napoleone, G., Sagri, M., 1993. Palaeomagnetic calibration of Late Villafranchian mammalian faunas from the Upper Valdarno, Central Italy. Memorie della Società Geologica Italiana 49, 335-344.

Trauth, M.H., Larrasoaña, J.C., Mudelsee, M., 2009. Trends, rhythms and events in PlioPleistocene African climate. Quaternary Science Reviews 28, 399-411.

Tsatskin, A., Heller, F., Gendler, T.S., Virina, E.I., Spassov, S., Du Pasquier, J., Hus, J, Hailwood, E.A., Bagin, V.l., Faustov, S.S., 2001. A new scheme of terrestrial paleoclimate evolution during the last $1.5 \mathrm{Ma}$ in the Western Black Sea Region: integration of soil studies and loess magmatism. Phys. Chem. Earth (A) 26 (11-12), 911-916.

Turner, A., 1999. Assessing earliest human settlemeent of Eurasia: Late Pliocene dispersions from Africa. Antiquity 73, 563-570 van der Made, J., Mazo, A.V., 2001. Spanish Pleistocene Proboscidean Diversity as a Function of Climate. In: Cavarretta, G., Gioia, P., Mussi, M., Palombo, M.R. (Eds.), The World of Elephants. Proceedings of the First International Congress. Consiglio Nazionale delle Ricerche, Rome, pp. 214-218.

Vermeersch, P.M., 2006. La vallée du Nil et le Sahara oriental : une population préhistorique fluctuante sous l'effet des variations climatiques. Comptes Rendus Palevol 5, 255-262.

Villa, P., 2001. Early Italy and the colonization of Western Europe. Quaternary International 75, 113-130.

Yokoyama, Y., Bibron, R., Falguères, C., 1988. Datation absolue des planchers stalagmitiques de la grotte du Vallonnet à Roquebrune-Cap-Martin (Alpes-Maritimes, France), par la résonance de spin électronique (ESR). L'Anthropologie 92, 429-436.

Zhao, J.-x., Hu, K., Xu, H.-k., 2001. Thermal ionization mass spectrometry U-series dating of a hominid site near Nanjing, China. Geology 29, 27-30. 